\title{
Centering the Inmigrant in the Inter/National Imagination
}

\author{
Robert S. Chang† \& Keith Aoki
}

In this Article, Professors Chang and Aoki examine the relationship between the immigrant and the nation in the complicated racial terrain known as the United States. Special attention is paid to the border which contains and configures the local, the national and the international. They criticize the contradictory impulse that has led to borders becoming increasingly porous to the flows of information, goods and capital while simultaneously constricting when it comes to the movement of certain persons, particularly those of Asian and Latinalo ancestry. The authors examine Monterey Park, California, as one site where there has been a large infiux of capital, information, and persons. Centering the immigrant in their analysis allows them to observe the interaction of

Copyright (1) 1997 California Law Review, Inc.

$\dagger$ Associate Professor, California Western School of Law; Visiting Associate Professor, Loyola Law School. A.B. 1988, Princeton University; M.A., J.D. 1992, Duke University. I have benefited from presenting portions of this Article at the Second and Third Asian Pacific American Law Professors Conference at, respectively, the John Marshall College of Law and UCLA Law School, the 1995 and 1996 Hispanic National Bar Association Annual Meeting held in, respectively, San Juan and Miami, the Faculty Lecture Series at the Washington College of Law at American University, the Center for the Study of Race and Ethnicity at UCSD, the Literature Department Colloquium Series at UCSD, and the 1995 Critical Networks Conference at American and Georgetown Universities. Thanks go to the participants at these gatherings for their comments. Work on this project was aided by a publication award from California Western School of Law.

$¥$ Associate Professor, University of Oregon School of Law. B.F.A. 1978, Wayne State University; M.A. 1986, Hunter College; J.D. 1990, Harvard University; LL.M. 1993, University of Wisconsin. I have benefited from presenting portions of this Article at the Third Asian Pacific American Law Professors Conference at UCLA Law School, the 1996 Hispanic National Bar Association Annual Mceting in Miami, the 1996 New Approaches to International Law Conference at the University of Wisconsin-Madison, the 1996 New Approaches to Comparative Law Conference at the University of Utah College of Law, the 1997 Third World Approaches to International Law and the 1997 Fin-de-Nail Conferences, both at Harvard Law School. Thanks go to the participants at those gatherings. I would also like to thank my friends Steve Bender, Maggie Chon, Garrett Epps, Ibrahim Gassama, Lisa Iglesias, Lisa Ikemoto, Kevin R. Johnson, Lisa Kloppenberg and Frank Valdes for their comments and criticisms. I would also like to thank Anne Fujita, David Munsey and Mary Anne Murk for their superb research assistance. 
national borders and the construction of racial subjects as community members negotiate electoral politics and coalition building.

\section{INTRODUCTION}

How a nation treats the immigrant speaks volumes about the nation. This is especially true for the United States, which regards itself as a nation of immigrants. ${ }^{2}$ How the United States treats the immigrant is part of the "project of national self-definition .... [which] includes not only deciding whom to admit and expel, but also providing for each alien's transition from outsider to citizen."3 A critical examination of this project may help us negotiate the tensions created by changing demographics as we decide what sort of nation we want to be.

The immigrant signifies a person in a specific relation to the nation and contains within it a sense of movement: the immigrant has moved or

1. This statement incorporates the notion of subject positions where the immigrant describes one subject position of a person in a specific relation to the nation. By subject position, we mean the following:

Within every society, each social agent is inscribed in a multiplicity of social relations-not only social relations of production but also the social relations, among others, of sex, race, nationality, and vicinity. All these social relations determine positionalities or subject positions and every social agent is therefore the locus of many subject positions and cannot be reduced to only one.... Furthermore, each social position, each subject position, is itself the locus of multiple possible constructions, according to the different discourses that can construct that position.

Chantal Mouffe, Hegemony and New Political Subjects: Toward a New Concept of Democracy, in MARXISM AND THE INTERPRETATION OF Culture 89-90 (Cary Nelson \& Lawrence Grossberg eds., 1988).

In addition to describing a subject position, the immigrant also exists as a discursive formation that is itself a site of contested meanings. By discursive formation, we mean:

Whenever one can describe between a number of statements, such a system of dispersion, whenever, between objects, types of statement, concepts or thematic choices, one can define a regularity (an order, correlations, positions and functionings, transformations), we will say, for the sake of convenience, that we are dealing with a discursive formation.... The conditions to which the elements of this division (objects, mode of statements, concepts, thematic choices) are subjected we shall call the rules of formation. The rules of formation are conditions of existence (but also coexistence, maintenance, modification, and disappearance) in a given discursive division.

Michel Foucault, The ARChaeology of KNowledge 38 (A.M. Sheridan Smith trans., 1972).

2. Throughout United States history, politicians and scholars have celebrated this aspect of American exceptionalism. For one overview, see ARThur M. Schlesinger, JR., The Disuniting of America: Reflections on a Multicultural society (1992). See also Gabriel J. Chin, The Civil Rights Revolution Comes to Immigration Law: A New Laok at the Inmigration and Nationality Act of 1965, 75 N.C. L. REv. 273, 339-45 (1996) (discussing the comments of various political leaders on immigration, assimilation and the melting pot).

3. Hiroshi Motomura, Whose Alien Nation?: Two Models of Constitutional Inmigration Law, 94 MrCH. L. REv. 1927, 1944-45 (1996). This project of national self-definition vis-à-vis the immigrant inevitably intersects with the project of national self-definition vis-d-vis this country's racial minorities. We discuss the implications of this infra Part I. 
is moving, crossing a border to get from "there" to "here." What negotiations must the immigrant make in traversing the border to gain entry into the United States? Once "inside," what other borders remain? The immigrant may learn after crossing the border that she has not left it behind, that the border is not just a peripheral phenomenon. ${ }^{4}$ She may learn, through the juridical and extrajuridical policing of the border, that she carries the border with her. Indeed, to be an immigrant is to be marked by the border. This is not to say that all immigrants are marked in the same way. Soine immigrants are able to "pass" while others (and sometimes even their U.S.-born descendants) remain perpetual foreigners. ${ }^{5}$

One key component in the construction of the inmigrant and its relation to the nation is the operation of the border in constructing identities. The border is not something "found" on the geo-political periphery. Instead, the border is itself a social construct, and it is through its flexible operation that the border helps to construct and contain the nation and the national community.

By defining the national, the border represents a bridge (and barrier) between the national and the international. The border connects (and interrupts) the inter/national such that it is the enabling condition

4. One example of this is the U.S. Immigration and Naturalization Service (INS) border checkpoint on Interstate 5 approximately halfway between San Diego and Los Angeles, a point that is many miles from the literal United States-Mexico border. We discuss other examples of this below.

5. In pursuing this line of inquiry, we follow Neil Gotanda, whose work on non-Black minorities first explored "foreignness" as a "previously unexamined dimension of the relationship between race and law." Neil Gotanda, "Other Non-Whites" in American Legal History: A Review of Justice at War, 85 CoLum. L. REv. 1186, II88 (1985) (book review). Gotanda makes this point more explicitly in a later work:

[W]ithin the United States, if a person is racially identified as African American or white,

that person is presumed to be legally a U.S. citizen and socially an

American.... [However,] these presumptions are not present for Asian Americans, Latinos, Arab Americans, and other non-Black racial minorities. Rather, there is the opposite presumption that these people are foreigners; or, if they are U.S. citizens, then their racial identity includes a foreign component.

Neil Gotanda, Asian-American Rights and the "Miss Saigon Syndrome," in Asian Americans AND THE Supreme Court 1096 (Hyung-chan Kim ed., 1992).

A number of scholars have commented on the way foreignness is attributed to certain groups regardless of birthplace. See, e.g., Robert S. Chang, Toward an Asian American Legal Scholarship: Critical Race Theory, Post-Structuralism, and Narrative Space, 81 CaLIf. L. Rev. 1241, 1258, 1 Asian L.J. 1, 18 (1993); Pat K. Chew, Asian Americans: The "Reticent" Minority and Their Paradoxes, 36 WM. \& MARY L. REv. 1, 33-38 (1994); Kevin R. Johnson, Some Thoughts on the Future of Latino Legal Scholarship, 2 HaRv. LatiNo L. Rev. (forthcoming 1997) (manuscript at 17 19, on file with author); Juan F. Perea, Los Olvidados: On the Making of Invisible People, 70 N.Y.U. L. Rev. 965, 988-90 (1995); Natsu Saito, Alien and Non-Alien Alike: Citizenship, "Foreignness" and Racial Hierarchy in American Law, 76 OR. L. REv. (forthcoming 1997) (manuscript at 62-65, on file with author). 
for conceptions of both the national and the international. Some analysts, prompted by the increasing flow of goods, information and capital across borders, have heralded the end of the nation-state. ${ }^{6}$ However, news of the nation-state's demise is premature. Although borders have become increasingly porous to flows of information and capital, borders are constricting when it comes to the movement of certain persons. ${ }^{7}$ While increasing information and capital flows, coupled with the rise of transnational corporations, have led to a reconfiguration of nationstates, ${ }^{8}$ the constriction of the movement of certain persons across borders has led to a rearticulation or renewal of the nation-state, often expressed along problematic racialized lines. ${ }^{9}$ Stated differently, the nation-state is reasserting (and perhaps re-creating) itself through control over immigration and the immigrant.

In Part I, we examine the entry of the immigrant into the racialized space of the United States. Centering our analysis on the immigrant tells us much about the political economies of race and nativistic racism, which operate to construct immigrant, racial, and national identities. In Part II, we examine the operation of the border and its role in constructing the nation and the national community. In Part III, we examine Monterey Park, California, as one site where the intra- and international spheres meet. There has been a large influx of capital, information, and persons into Monterey Park, allowing us to observe the interaction of national borders and the construction of racial subjects as community members negotiate electoral politics and coalition building.

This process of placing the immigrant at the center of the analytical discourse on the social construction of borders and national identitycentering the immigrant-offers one model for how LatCrit discourse and Asian American legal scholarship may contribute to the understanding of Latina/os and Asian Americans in the complex terrain of United States race relations.

6. See, e.g., Francis Fukuyama, The End of History and the Last Man (1992); JeanMarie Guehenno, The END of The Nation-State (Victoria Elliot trans., 1995).

7. This is particularly curious, because it is the very flow of capital across national borders that helps create the flow of people. The developed world uses porous borders to extract resources from the rest of the world, which disrupts the economies and cultures of the developing world, sending people whose societies have been disrupted by war, inflation, or environmental degradation to developed nations in the form of immigration.

8. This is evidenced by trade agreements such as the GATT or NAFTA and the creation of the European Community. See David J. Elkins, Beyond Sovereignty (1995); Keith Aoki, (Intellectual) Property and Sovereignty: Notes Toward a Cultural Geography of Authorship, 48 STAN. L. REv. 1293 (1996).

9. See infra Part II. 


\section{I}

\section{THE IMMIGRANT AND THE INTER/NATIONAL}

Examining the immigrant's entry into and presence in the racialized space of the United States provides an opportunity to explore the racial structures that undergird and constitute this nation-state. We might question official state apparatuses such as the census, which might be described as an official identity producer, and its role in (re)producing racialized subjects. ${ }^{10}$ We might question legal doctrines, such as equal protection, and their role in producing racialized identities while simultaneously mandating color-blindness on the part of public actors. ${ }^{11}$ The point of the critique is not to abandon race, but rather to examine the political economy of race, the processes through which race is used to distribute power and maintain racial privilege. These processes produce and maintain both immigrant and native identities. Examination of the immigrant allows us to observe the dynamics of racial formation ${ }^{12}$ as immigrants enter the political/cultural/legal space of the United States and "become" differentially racialized as Asian

10. For some critical examinations of the operation of the census, see Christine B. Hickman, The Devil and the One Drop Rule: Racial Categories, African-Americans and the U.S. Census, 95 Mich. L. Rev. 1161 (1997); Kenneth E. Payson, Comment, Check One Box: Reconsidering Directive No. 15 and the Classification of Mixed-Race People, 84 CALIF. L. Rev. 1233 (1996); Gloria Sandrino, Los Confudidos: De-Conflating Latinos/as' Race and Nationality (May 1, 1996) (unpublished manuscript, on file with author); Luis Angel Toro, "A People Distinct from Others": Race and Identity in Federal Indian Law and the Hispanic Classification in OMB Directive No. 15, 26 TEX. TECH L. REv, 1219 (1995).

11. For recent Supreme Court opinions reflecting an adherence to color-blindness, see Miller v. Johnson, 515 U.S. 900 (1995) (color-blindness and voting districts); Adarand Constructors, Inc. v. Pena, 515 U.S. 200 (1995) (color-blindness and government contracting); and Missouri v. Jenkins, 515 U.S. 70 (1995) (color-bhindness and school desegregation). For a criticism of these decisions, all from the 1994-95 Term of the United States Supreme Court, see Robert L. Hayman, Jr., \& Nancy Levit, The Tales of White Folk: Doctrine, Narrative, and the Reconstruction of Racial Reality, 84 Calif. L. Rev. 377 (1996) (reviewing Richard Delgado, The Rodrigo Chronicles: CoNversations aboUt AMERICA AND RACE (1995)). For general criticisms of color-blind constitutionalism, see Garrett Epps, Of Constitutional Seances and Color-Blind Ghosts, 72 N.C. L. REv. 401 (1994); Neil Gotanda, A Critique of "Our Constitution is Color-Blind," 44 STAN. L. Rev. 1 (1991).

12. We use racial formation in the sense articulated by Michael Omi and Howard Winant:

We define racial formation as the sociohistorical process by which racial categories are created, inhabited, transformed, and destroyed. ... First, we argue that racial formation is a process of historically situated projects in which human bodies and social structures are represented and organized. Next we link racial formation to the evolution of hegemony, the way in which society is organized and ruled.

Michael OMi \& Howard Winant, Racial Formation In The United States: From the 1960 s to THE 1990s, at 55-56 (2d ed. 1994). We also adhere to their definition of race as "a concept which signifies and symbolizes social conflicts and interests by referring to different types of human bodies." Id. at 55 (emphasis omitted). 
American, Black, Latina/o, and White. ${ }^{13}$ It is important to note, though, that this is not a one-way process-as immigrants "become" Asian American, Black, Latina/o, and White, these racial formations are themselves subject to reconfiguration and may become focal points around which one organizes a politics of identity.

The differential racialization of immigrants is evident in the different treatment accorded White immigrants when compared with those from Africa, Asia, the Caribbean, and Latin America. ${ }^{14}$ Fear of immigration, often discussed in generalized terms, is colored so that only certain immigrant bodies excite fear. In the midst of cries to limit legal immigration, the Immigration Act of 1990 included legislation to encourage immigration from northwestern European countries such as Ireland. ${ }^{15}$ In the midst of cries to limit illegal immigration, the figure of the Mexican border-crosser or of the Chinese boat person makes the evenimg news, whereas the fact that Italians constitute the largest group of undocumented immigrants in New York is obscured. ${ }^{16}$ (After the Italians, the most numerous groups of undocumented immigrants in New York come from Ecuador, Poland, Ireland, and Russia. ${ }^{17}$ ) These examples show how the "problem" of legal and illegal immigration is colored in the national imagination: fear over immigration is not

13. Although some work has been done in this area, much work remains. Recent work that has paid special attention to the racialization of immigrants (at differing levels of temporal and geographic specificity) includes: Theodore W. Allen, The Invention of the White Race (1994); Robert S. Chang, Dis-Oriented: Asian Americans, Law, and the Nation-State (forthcoming 1998); Yen Le ESPIRITU, Asian AMERICAN PANETHNicitY: BRidging INSTITUTIONS and Identities (1992); Noel Ignatiev, How the Irish Become White (1995); Lisa Lowe, Immigrant Acts: ON Asian American Cultural Politics (1996); Suzanne Oboler, Ethnic Labels, Latino Lives: Identity and the Politics of (Re)Presentation in the UNITED States (1995); David R. Roediger, The Wages of Whiteness: Race and the Making of the AMerican Working Class (1991); George J. SANChez, Becoming Mexican American: EthNicity, Culture, and Identity in Chicano Los ANgEles, 1900-1945 (1993); Tekle Mariam Woldemikael, Becoming Black american: Haitians and American INSTITUTIONS IN EVANSTON, ILLINOIS (1989).

14. This political economy is not just articulated and enforced in terms of White versus nonWhite. Cf. Peter Brimelow, Alien Nation 191-221 (1995) (setting out the different threats from various immigrant groups).

15. See Dennis Conway, Are There New Complexities in Global Migration Systems of Consequence for the United States "Nation-State"?, 2 IND. J. Global LEGAl STud. 31, 41-42 (citing lmmigration Act of 1990, Pub. L. No. 101-649, $\S 132,104$ Stat. 4978, 5000 (codificd as amended at 8 U.S.C. $\$ 1153$ (Supp. V 1993)).

16. See Leti Volpp, Talking "Culture": Gender, Race, Nation, and the Politics of Multiculturalism, 96 ColUM. L. Rev. 1573, 1605 (1996) (citing Jeff Yang \& Karen Lam, Could It Happen Here?, VillaGe VoICE, Dee. 6, 1994, at 14). Obviously, the composition of undocumented immigrants varies depending on the geographic locale.

17. Id. 
articulated solely arouud foreignness per se; it includes a strong racial dimension. ${ }^{18}$

Etienne Balibar, writing in the European context, describes the new racism, centered around the category of immigration, as:

a racism of the era of "decolonization," of the reversal of population movements between the old colonies and the old metropolises, and the division of humanity within a single political space.... It is a racism whose dominant theme is not biological heredity but the insurmountability of cultural differences, a racism which, at first sight, does not postulate the superiority of certain groups or peoples in relation to others but "only" the harmfulness of abolishing frontiers, the incompatibility of lifestyles and traditions; in short, it is what P.A. Taguieff has rightly called a differentialist racism. ${ }^{19}$

In the United States, this differentialist racism might be termed nativistic racism. Nativistic racism is not just an intersectional term, but signifies that both nativism and racism are mutually constitutive of the other and operate in tandem to preserve a specific conception of the nation. ${ }^{20}$

18. Sometimes, this racial dimension is rearticulated in cultural terms. See Volpp, supra note 16, at 1600-07 (describing the cultural racism in Doriane Coleman, Individualizing Justice Through Multiculturalism: The Liberals' Dilemma, 96 Colum. L. Rev. 1093 (1996)).

19. Etienne Balibar, Is There a "Neo-Racism"?, in RACE, Nation, Class: Ambiguous IDENTIrIES 17, 21 (Etienne Balibar \& Immanuel Wallerstein eds. \& Chris Turner trans., 1991) (footnote omitted). This "differentialist racism" is precisely the basis of pluralism as articulated in the United States in the first quarter of this century. Compare Balibar's words with those of Lothrop Stoddard, who wrote in the early part of this century:

No theoretical questions of 'superiority' or 'inferiority' need be raised... . The really important point is that even though America (abstractly considered) may not be nearly as good as we think it is, nevertheless it is ours. ... That is the meat of the matter, and when we discuss immigration we had better stop theorizing about superiors and inferiors and get down to the bedrock of difference.

Lothrop Stoddard, Re-Forging America; THE STORY OF OUR Nationhood 103 (1927), quoted in Walter Benn Michaels, Our America: Nativism, Modernism, and Pluralism 65 (1995). We see, then, the dark side of pluralism, which entails that "the commitment to difference itself represents a theoretical intensification rather than diminution of racism, an intensification that has nothing to do with feelings of tolerance or intolerance toward other races and everything to do with the conceptual apparatus of pluralist racism." MiCHAELs, supra, at 65.

20. Many commentators discuss racism and nativism together as part of a list. See, e.g., Lynne Henderson, Authoritarianism and the Rule of Law, 66 IND. L.J. 379, 380 (1991) (noting the recent "resurgence of active manifestations of racism, anti-semitism and nativism") (footnotes omitted); David A. Martin, Due Process and Membership in the National Community: Political Asylum and Beyond, 44 U. PITT. L. Rev. 165, 204 (1983) (describing patriotism as "the vehicle for racist or nativist policies"). Rather than think of the terms as co-equal, Kenneth Karst explores the intersection of racism and nativism, commenting that the belief "that full membership in America would be extended to all who would embrace the nation's ideals ... was so easily twisted into racist nativism." Kenneth L. Karst, Belonging to America: EQual Citizenship and the Constirurion 84 (1989). Likewise, John Higham, in his brilliant examination of American nativism, 
The nativist movements directed against immigrants from Southern and Eastern Europe, immigrants who were ostensibly White, reflect the constitutive relationship between nativism and racism. As John Higham demonstrates, nativism against those groups did not gain real currency until scientific racism provided a language that allowed them to become targets of nativistic racism. Southern and Eastern European immigrants were represented as racially other to "White" Americans and could therefore be discriminated against. ${ }^{21}$ To combat this discrimination, these immigrants engaged in an identity politics in which they claimed a White identity. ${ }^{22}$ This eventually proved to be a successful strategy-by claiming a White identity, they could become "American" and escape the animus of nativistic racism. ${ }^{23}$

Blacks, already present in the geographic space of the United States, posed a different problem. Ironically, the granting of freedom and formal national membership to Blacks provided the predicate for a new form of racial nationalism, the ideology underwriting " $[t]$ he identification of American with White (and the colonization or, failing that, segregation of blacks). ${ }^{.24}$ The demise of the master/slave relationship and the formal ban against racial discrimination necessitated new technologies of racism to preserve White privilege. The Supreme Court provided a new technology in Plessy v. Ferguson, setting forth the "separate but equal" doctrine that marked

a new development in racial thinking... [that] affirmed racial distinction as such; it affirmed, that is, racial distinction independent of any other legal consideration so that the relation between black and white was radically distinguished from the relation between master and slave. Slaves, in principle, could become free; blacks could never become white. ${ }^{25}$

Racial nationalism, or "the identification of American with white," required that Blacks never become American. The doctrine of "separate

uses the term "racial nativism" to examine the "intersection of racial attitudes with nationalistic ones." This provided the vocabulary or technology that enabled "the extension to [certain] European nationalities of that sense of absolute difference which already divided white Americans from people of other colors." John Higham, Strangers in the Land: Patterns of American Nativism, $1860-1925$, at 132 (2d ed. 1988). In a recent work, Leti Volpp refers to this as cultural nationalism. See Volpp, supra note 16 , at 1605.

21. See Higham, supra note 20 , at 132.

22. See IGNATIEv, supra note 13, at 1-3; RoEDIGER, supra note 13 .

23. See IGNATIEv, supra note 13, at 1-3; RoEDiger, supra note 13 .

24. Walter Benn Michaels, The Souls of White Folk, in Literature AND THE Body: EsSAYS on Populations and Persons 185, 188 (Elaine Scarty ed., 1988).

25. Id. at $188-89$. 
but equal" enabled the economic disempowerment, political disfranchisement, and physical terrorization of Blacks, preserving the national community as White.

From these examples, we see that nativistic racism and racial nationalism helped to construct Black and White as racial and national formations. ${ }^{26}$ In a similar fashion, nativistic racism and racial nationalism have helped to construct Asian American and Latina/o as racial and national formations. ${ }^{27}$

These formations, though, are not static. It is important to note that nativistic racism, which constructs "immigrants" as Asian American, Black, Latina/o, and White, is not a one-way process. These racial and national formations are themselves subject to reconfiguration. Stated more strongly, immigrants, in addition to introducing and representing diversity, remind us of the diversity already present-that Asian American, Black, Latina/o, and White communities are and have always been "heterogenous, hybrid, and multiple."28 While many scholars have commented on the tremendous diversity within the Asian American and Latina/o formulations, ${ }^{29}$ relatively little attention has been paid to the new immigration that is bringing an increased diversity to Black communities. ${ }^{30}$ Further, despite the growing literature on Whiteness as a racial phenomenon, ${ }^{31}$ insufficient attention has been paid to the diversity encompassed within Whiteness.

26. By "national formation," we mean the nominal form, paraphrasing Omi and Winant on racial formation, of the sociohistorical process by which national categories are created, inhabited, transformed, and destroyed. See OMI \& WINANT, supra note 12, at 55-56. By linking "race" and "nation," we hope to avoid universalizing "race," in recognition of the importance of temporal and spatial specificity.

Nativistic racism or racial nationalism has also operated to construct Native American identities. Native Americans occupy a unique position in the racial economy of the United States because of their quasi-sovereign status.

27. See infra Part II (exploring how nativistic racism and the operation of the border work to construct Asian American identities).

28. Lisa Lowe, Heterogeneity, Hybridity, Multiplicity: Marking Asian American Differences, 1 Diaspora 24 (1991).

29. See, e.g., Lowe, supra note 13 ; Chew, supra note 5, at 25-31; Berta Esperanza Hernández Truyol, Building Bridges-Latinas and Latinos at the Crossroads: Realities, Rhetoric and Replacement, 25 ColuM. HuM. RTs. L. Rev. 369, 383-96 (1994).

30. Some exceptions include Conway, supra note 15 , at 33 ("[N]ew immigration from such non-traditional source regions as Africa, the Caribbean, and South Asia is bringing multicultural plurality to the Black- or African-American community."); see also WoldEMIKAEL, BECoMING BLACK AMERICAN, supra note 13.

31. See generally Allen, supra note 13; Ruth Frankenberg, White Women, Race Matters: The Social Construction of Whiteness (1993); Ian F. Haney López, White by LAW: The Legal Construction of RAce (1996); Roediger, supra note 13; Barbara J. Flagg,

"Was Blind, But Now I See": White Race Consciousness and the Requirement of Discriminatory 
Examination of the immigrant requires us to take pluralism seriously and creates the discursive space for an enriched discussion of what it means to be a nation. ${ }^{32}$ It forces us to remember that multiculturalism is not just about recognizing and respecting the presence of minority cultures against the backdrop of a dominant, White Euro-American culture; multiculturalism requires us to recognize and respect the heterogeneity within minority and majority communities. ${ }^{33}$

Although nativistic racism tends to disgnise the diversity within broad racial categories, it also creates the enabling condition for ethnic and racial identity politics. Despite the outlawing of formal discrimination, ${ }^{34}$ the United States remains a hierarchical society that has failed to live up to its democratic principles. Responding to nativistic racism may help us develop an emancipatory politics that will move us toward what

Intent, 91 Mich. L. REv. 953 (1993); Cheryl I. Harris, Whiteness as Property, 106 HaRv. L. Rzv. 1707 (1993); George Lipsitz, The Possessive Investment in Whiteness: Racialized Social Democracy and the "White" Problem in American Studies, 47 AM. Q. 369 (1995).

For some recent work on the interconnectedness of Whiteness and Blackness, see generally Passing AND THE Fictions of IDENTITY (Elaine K. Ginsberg ed., 1996); ERIC LoTT, Love AND Theft: Blackface Minstrelsy and the american Working Class (1993); Toni Morrison, Playing in the Dark: Whiteness and the Literary Imagination (1992); ERic J. Sundeuist, To Wake the Nations: Race in the Making of American Literature (1993); Shelley Fisher Fishkin, Interrogating "Whiteness," Complicating "Blackness": Remapping American Culture, 47 AM. Q. 428 (1995); Robert Westley, Left for Dead: Blackness and the "Passing" of White Authority (June 1, 1996) (unpublished manuscript, on file with author).

32. This is the discussion we undertake in Part 11I, in which we examine the potcntial and difficulties of coalition building in the complicated racial space called Monterey Park, California.

33. See generally LowE, supra note 13 (acknowledging diversity within identity groups in no way prevents identity politics); acknowledging diversity merely requires us to rethink the way we do our politics. We cannot make assumptions about a person's political orientation based on her racial identity. As Angela Harris reminds us:

There are no "people of color" waiting to be found; we must give up our romance with racial community.... If any lesson of the pohtics of difference can yet be identified, it is that solidarity is the product of struggle, not wishful thinking; and struggle means not only political struggle, but moral and ethical struggle as well.

Angela P. Harris, Foreword: The Jurisprudence of Reconstruction, 82 CALIF. L. REV. 741, 784 (1994). Randall Kennedy, commenting on the work of Alan Freeman and Mari Matsuda, makes a similar point. See Randall L. Kennedy, Racial Critiques of Legal Academia, 102 HARv. L. REV. 1745, 1799-1800 (1989) ("Both Freeman and Matsuda are mistaken, however, in believing that a person's racial status compels him to contribute to struggles against racism.").

34. As Alan Freeman writes:

[A]s surely as the law has outlawed racial discrimination, it has affirmed that Black Americans be without jobs, have their children in all-black, poorly funded schools, have no opportunities for decent housing, and have very little political power, without any violation of antidiscrimination law.

Alan D. Freeman, Legitimizing Racial Discrimination Through Antidiscrimination Law: A Critical Review of Supreme Court Doctrine, 62 MinN. L. REv. 1049, 1050 (1978). 
Ernesto Laclau and Chantal Mouffe describe as "a radical and plural democracy":

In the face of the project for the reconstruction of a hierarchic society, the alternative of the Left should consist of locating itself fully in the field of the democratic revolution and expanding the chain of equivalents between the different struggles against oppression. The task of the Left therefore cannot be to renounce liberal-democratic ideology, but on the contrary, to deepen and expand it in the direction of a radical and plural democracy. ${ }^{35}$

Instead of advocating sameness, the "concept of solidarity" may be invoked to establish a "chain of equivalents" between the different groups and their struggles against oppression. ${ }^{36}$

For people of color in the United States, we might begin with the ideology of White supremacy which permitted the genocide of Native Americans, the enslavement of Africans, the conquest and dispossession of Mexicans, and the exclusion of Asians. But White supremacy located within the confines of the nation-state tells only part of the story. There is, unfortunately, a rich history of colonialism and imperialism in their traditional and contemporary forms. ${ }^{37}$ Once we escape the confines of a national imagination, it becomes easier to deepen the chain of democratic equivalents, linking the struggles of those who have been in the United States for generations with the struggles of those who have arrived more recently. The difficulties for this project are brought into sharp focus when we consider in Part III the operation of nativistic racism and the political economy of race in the city of Monterey Park, California.

Before we turn to that discussion, we will explore the operation of nativistic racism through the construction of the border.

35. Ernesto laclau \& Chantal Mouffe, Hegemony and Socialist Strategy: Toward a Radical Democratic Politics 176 (Winston Moore \& Paul Cammack trans., 1985).

36. Chantal Mouffe, Hegemony and New Political Subjects: Toward a New Concept of Democracy, in MARXISM AND THE INTERPRETATION OF Culture, supra note 1, at 89, 100.

37. See generally De-Scribing Empire: Post-Colonialism and Textuality (Chris Tiffin \& Alan Lawson eds., 1994). 
II

National Identity CRISIS AND THE ReINSCRIPTION OF BORDERS ${ }^{38}$

In this Part, we begin by examining the larger glabal events that have shaped the local. The so-called new world order is accompanied by a new local order in which immigrants have replaced the threat of communism in the national imagination. We continue by examining how the anxiety engendered by these events has spurred a renewed policing of the border, with Asian Americans and Latina/os as the special targets of nativistic racism in this new world/lacal order.

\section{A. The Immigrant as the Other in the New World/Local Order}

In the poem Mending Wall, Robert Frost wrote of two neighbors and their spring ritual when each would "set the wall between [them] once again." 39 When the narrator questions the need for a wall in certam places, the neighbor replies as did his father, "Good fences make gaad neighbours." ${ }^{40} \mathrm{He}$ refuses to ask why, whereas the narrator is full of questions: "Before I built a wall I'd ask to know/What I was walling in or walling out,/And to whom I was like to give offence."4l Before the United States finishes building a wall between itself and Mexico, ${ }^{42}$ we would like to know what we are walling in and walling out. This preaccupation with the U.S.-Mexico border is symptomatic of an unreflective nationalism that may have dire consequences for us as a nation.

This unreflective nationalism and focus on borders was fueled by the end of the Cold War, which precipitated an identity crisis for the United States. Without its ideological Other, against which it had defined itself, what role was the United States to take in the world? What was the new order to be? Iraq's invasion of Kuwait provided a convenient point for unveiling the new world order, announced by President George Bush "[a]s bombs were raining on Baghdad, Basra, and miserable conscripts hiding in holes in the sands of southern Iraq." ${ }^{43}$ The bombing of Iraq was consistent with the premises of this new world

38. This Part draws from and expands on an earlier work. See Robert S. Chang, A Meditation on Borders, in Immigrants Out!: The New Nativism aNd the ANTI-IMMigrant IMPULSE IN THE UNITEd STATES (Juan F. Perea ed., 1997).

39. Robert Frost, Mending Wall, in COMPLete PoEms of Robert Frost 47 (1964).

40. Id. at $94-95$.

41. Id. at 95 .

42. We find it ironic that the material used to build the fence recently erected at part of the U.S.-Mexico border near San Diego was originally used as temporary airstrips during our imperial encounter in Vietnam. We thank Kevin Johnson for apprising us of this fact. Conversation with Kevin R. Johnson, Professor of Law, University of California at Davis (Oct. 3, 1996).

43. Noam Chomsky, World ORders, Old and New 7 (1994). 
order: "unless international boundaries between sovereign nation states are respected, the alternative is chaos." $" 44$

The end of the Cold War also allowed attention to turn inward. In the context of Western Europe, Chantal Mouffe observes:

Now that the enemy [communism] has been defeated, the meaning of democracy itself has become blurred and needs to be redefined by the creation of a new frontier. This is much more difficult for the moderate right and for the left than for the radical right. For the latter has already found its enemy. It is provided by the "enemy within," the immigrants, which are presented by the different movements of the extreme right as a threat to the cultural identity and national sovereignty of the "true" Europeans."

Thus, the possibility of chaos is not restricted to the international sphere. Chaos may come from within. For the United States, which is not at much risk of literal invasion by another nation-state, its cultural identity and national sovereignty may be at greater risk of "invasion" by immigrants and would-be immigrants. ${ }^{46}$

Many White Americans believe that the "invasion," or coming majority of color, has already eclipsed the numerical White majority. A recent poll reported in the New York Times reveals that many White Americans exaggerate the number of racial minorities present in this country:

Percentage of the United States population that white Americans think is Hispanic: 14.7

Percentage that is Hispanic: 9.5

Percentage that white Americans think is black: 23.8

Percentage that is black: 11.8

Percentage that white Americans think is Asian: 10.8

Percentage that is Asian: 3.1

Percentage that white Americans think is white: 49.9

Percentage that is white: $74^{47}$

44. Id. (quoting Thomas L. Friedman, Today's Threat to Peace is the Guy Down the Street, N.Y. TIMES, June 2, 1991, §4, at E3).

45. Chantal Mouffe, The Return of the Political 3-4 (1993).

46. This sense of invasion is captured in a statement made by Ruth Coffey, the head of Stop lmmigration Now: "I have no intention of being the object of 'conquest,' peaceful or otherwise, by Latinos, Asians, blacks, Arabs or any other group of individuals who have claimed my country." Timothy Christenfeld, Alien Expressions: Wretched Refuse is Just the Start, N.Y. Times, March 10, I996, § 4, at 4.

47. Priscilla Labovitz, Immigration-Just the Facts, N.Y. TIMEs, March 25, 1996, at A19. 
This poll demonstrates that many White Americans think that the "conquest" is well under way.

The logic of the new world order requires that conquest be resisted: our borders must be protected from the unlawful encroachment of certain foreigners and their cultures. This is to be accomplished through a renewed policing of national and institutional boundaries through immigration restrictions, affirmative action rollbacks, curriculum control, and welfare reform. Undocumented and legal immigrants, including naturalized citizens, have become the targets of recent political attacks. ${ }^{48}$ The new world order is accompanied by a new local order where membership in the national community is being constricted ${ }^{49}$

This creates a special problem for those of us who are perceived as foreign, because foreignness is used as a proxy for exclusion from the national community, such that our demands for justice and fair treatment may be ignored. We hear the response, "[i]f you don't like it here, go back where you came from." But many of us do not have a place to which to return. For many, that place exists only as an "imaginary homeland." 50

This sense of in-between-ness, of being not quite part of the (imagined) national community and yet not having a homeland, is a strong component of Asian American and Latina/o identities. ${ }^{51}$ In this Part, we will focus on the experiences of Asian Americans as this is our

48. Recent welfare reform measures permit individual states to limit public benefits to all classes of immigrants. See Linda S. Bosniak, Opposing Prop. 187: Undocumented Immigrants and the National Imagination, 28 CoNN. L. REv. $555,556 \mathrm{n} .3$ (1996). States that have taken advantage of these provisions include California and Pennsylvania.

49. Yasemin Nuhoglu Soysal, writing in the context of contemporary European nation-states, takes the opposite view, stating that "[a] new and more universal concept of citizenship has unfolded in the postwar era, one whose organizing and legitimating priuciples are based on universal personhood rather than national belonging." YASEMIN NuHOGLU SOYSAL, LimiTS OF Citizenship: Migrants and Postnational Membership in Europe 1 (1994). Without commenting on the validity of her thesis in the European context, I would argue that the recent welfare reform legislation in the United States that allows states to limit welfare to citizens demonstrates the renewed importance of national belonging in the United States context.

50. Salman Rushdie, Imaginary Homelands, in IMAgINARY Homelands: EsSays AND CRITICISM 1981-1991, at 9 (1991).

51. We draw the assertion that the national community is largely an imagined one from Benedict Anderson, Imagined Communities: Reflections on the Origin and Spread of Nationalism (2d ed. 1991). Anderson writes:

It is imagined because the members of even the smallest nation will never know most of their fellow-members, meet them, or even hear of them, yet in the minds of each lives the image of their communion. ... [I]t is imagined as a community, because regardless of the actual inequality and exploitation that may prevail in each, the nation is always conceived as a deep, horizontal comradeship.

Id. at 6-7. 
area of expertise and lived experience. We both grew up in the Midwest ${ }^{52}$ where people who looked like us existed as "Orientals," as the objects of U.S. orientalism..$^{53}$ We will at various points draw linkages with Latina/o experiences and the challenges presented for a LatCrit discourse and for Asian American legal scholarship.

\section{B. Asian Americans in the National Imaginary}

In Part I, we discussed nativistic racism and its role in constructing Black and White identities. ${ }^{54}$ In this section, we explore how nativistic racism regulates the lives of Asian Americans and helps to demarcate the boundaries of the American national community and its national identity.

Some of the effects of nativistic racism are evident in the rise of the English-Only movement, ${ }^{55}$ in California's Proposition 187, which would deny education, health care, and other social services to undocumented immigrants, ${ }^{56}$ and in the Federal Welfare Reform Act of 1996, which enables states to deny welfare eligibility to non-citizen legal residents. Proposition 187 has spawned copycat legislation and initiatives in other states as well as a federal imitator, dubbed the Personal Responsibility

52. Keith grew up in Michigan. Robert grew up in Ohio.

53. The beginning point for understanding Orientalism is Edward Said's description:

[T] he Orient has helped define Europe (or the West) as its contrasting image, idea, personality, experience. Yet none of this Orient is merely imaginative. The Orient is an integral part of European material civilization and culture. Orientalism expresses and represents that part culturally and even ideologically as a mode of discourse with supporting institutions, vocabulary, scholarship, imagery, doctrines, even colonial bureaucracies and colonial styles.

EdWARd W. SAID, ORIENTALISM 1-2 (1978). Thus, when we speak of U.S. orientalism, we understand, as did Said and Lisa Lowe, that it has its own specificities. See Lisa LowE, Critical TERRAINS: FRENCH AND BRITISH ORIENTALISMS ix (1991) ("[Orientalism does not] monolithically construct[] the Orient as the Other of the Occident...."); SAID, supra, at 1 (conceding that Americans will have a different relationship with the Orient, "which for them is much more likely to be associated with the Far East (China and Japan, mainly) ...."). We hope to explore how the Orient and "Orientals" form an integral part of U.S. material civilization, law, and culture.

54. See supra text accompanying notes 24-36.

55. See generally Antonio J. Califa, Declaring English the Official Language: Prejudice Spoken Here, 24 Harv. C.R.-C.L. L. REv. 293 (1989); Christopher David Ruiz Cameron, How the García Cousins Lost Their Accents: Understanding the Language of Title VII Decisions Approving Speak-English-Only Rules as the Product of Racial Dualism, Latino Invisibility, and Legal Indeterminacy, 85 CALIF. L. REv. 1347 (1997), 10 LA RAZA LJ. 261 (1997); Juan F. Perea, Demography and Distrust: An Essay on American Languages, Cultural Pluralism, and Official English, 77 MinN. L. REv. 269 (1992).

56. See generally Linda S. Bosniak, Membership, Equality, and the Difference that Alienage Makes, 69 N.Y.U. L. Rev. 1047, 1052 n.12 (1994). See also Bosniak, Opposing Prop. 187, supra note 48 , at 555-56. 
Act. ${ }^{57}$ These events bear a striking resemblance to the rapid spread of alien land laws in the early 1900s, which prevented those ineligible for citizenship from owning land. ${ }^{58}$ California, in 1913, was the first state to institute such a law. ${ }^{59}$ Other states soon followed suit. ${ }^{60}$ Although these laws targeted Asian immigrants as the only racial group ineligible for citizenship, they were written in race-neutral terms and thus survived constitutional challenge. ${ }^{61}$ Alien land laws gained new popularity with the advent of World War II; Utah, Wyoming, and Arkansas instituted such laws in 1943, shortly after the relocation of Japanese Americans to internment camps in these states. Like the earlier alien land laws, these were instituted to discourage settlement of "ineligible aliens."

If the history of the alien land laws is any indication, we will soon see Proposition 187 clones in the heartland of America, even in such places as Kansas. For example, if a Korean national flies from Seoul and lands in Kansas, the border will be there to greet her. The border is everywhere.

Although the border is everywhere, one's perspective may render it invisible. It is through this invisibility that the border gains much of its power. ${ }^{63}$ For one of us, the border was transparent until the following encounter, which was first described in an earlier article:

I think about the American border guard who stopped me when I tried to return to the United States after a brief visit to Canada. My valid Ohio driver's license was not good enough to let me

57. According to one news report published in January of 1995, Colorado, Florida, llinois, Louisiana, Minnesota, Missouri, Nebraska, Nevada, New York, Texas, Vermont, Washington, Wisconsin, and Wyoming were considering Proposition 187-style laws. See Lourdes Medrano Leslie, Group Seeks to Give State a Prop. 187: Wants Coast-Style Law on Illegals, ArIz. RePublic, Jan. 23, 1995, at B1.

58. Dudley O. McGovney, The Anti-Japanese Land Laws of Califormia and Ten Other States, 35 Calif. L. REv. 7 (1947).

59. Id.

60. $I d$.

61. See, e.g., Porterfield v. Webb, 263 U.S. 225 (1923) (upholding Califomia's alien land law); Terrace v. Thompson, 263 U.S. 197 (1923) (upholding Washington's alien land law).

62. McGovney, supra note 58 , at 9 . He also comments on the small number of Japanese aliens residing in states other than California that have alien land laws: "These states may, however, be retaining their 'ineligible alien' land laws out of fear that some of the Japanese aliens now residing in other states may move into them." $1 d$. at 17.

63. Barbara Flagg and Peggy McIntosh make a similar point with regard to the power of Whiteness through its invisibility or transparency. See Peggy McIntosh, Wellestey College Center for Research on Women, White Privilege and Male Privilege: A Personal Account of Coming to See Correspondences Through Work in Women's Studies (1988), reprinted in Power, Privilege, ANd Law: A Civil Rights Reader 22 (Leslie Bender \& Daan Braveman eds., 1995); Flagg, supra note 31. 
return to my country. He asked me where my passport was. I told him that I did not have one and that it was my understanding that I did not need one, that a driver's license was sufficient. He told me that a driver's license is not proof of citizenship. We were at an impasse.... [Meanwhile], the white man in the car in front of me at the border crossing did not have a problem with his driver's license. [No passport was asked of him.] ${ }^{64}$

In part, this story demonstrates that the properties of the border change depending on the contingent features of who or what is trying to get in or out.

We might draw an analogy from cell biology, comparing the cell wall or membrane, which is vital to the cell's existence, with the national border. Although there are obvious differences between a cell and a nation, the importance of the national border to the nation's survival is clear in the Supreme Court's border jurisprudence. According to the Court, Congress must be able to exercise plenary power, because a sovereign nation must exercise control over its borders-that is what it means to be a sovereign entity ${ }^{65}$ To hold otherwise would mean the end or death of the nation as a sovereign entity.

In the same way that the cell wall or membrane serves a screening function, the border operates to exclude that which is dangerous, unwanted, undesirable. In the Chinese Exclusion Case, which established the plenary power doctrine, the Supreme Court held that "[if Congress] considers the presence of foreigners of a different race in this country, who will not assimilate with us, to be dangerous to its peace and security ... its determination is conclusive upon the judiciary." The Court begins by stating that the Chinese are "foreigners of a different race," or what Neil Gotanda terms, racialized foreigners. ${ }^{67}$ These racialized foreigners "will not assimilate with us," which is, of course, a direct

64. Chang, Toward an Asian American Legal Scholarship, supra note 5,81 CALIF. L. REV. at 1258, 1 ASIAN L.J. at 18.

65. This relationship between a sovereign nation and its borders is made clear in the 1892 case of Nishimura Ekiu v. United States:

It is an accepted maxim of international law, that every sovereign nation has the power, as inherent in sovereignty, and essential to self-preservation, to forbid the cntrance of foreigners within its dominions, or to admit them only in such cases and upon such conditions as it may see fit to prescribe.

Nishimura Ekiu v. United States, 142 U.S. 651,659 (1892).

66. Chae Chan Ping v. United States, 130 U.S. 581, 605 (1889).

67. See Neil Gotanda, Towards Repeal of Asian Exclusion: The Magnuson Act of 1943, the Act of July 2, 1946, the Presidential Proclamation of July 4, 1946, the Act of August 9, 1946, and the Act of August 19, 1950, in AsIAN AMERICANS AND Congress: A Documentary History (Hyung-chan Kim ed., 1996). 
insult to us/U.S. This refusal to assimilate makes them dangerous to our peace and security. They are the Yellow Peril, threatening our sense of nation and of the national. Congress must exclude them at the border to preserve our nation. The (threatened) presence of the Clinese is presented as an issue of national security over which the Court relinquishes its jurisdiction.

The Court went one step further in the citizenship cases, holding, in essence, that Asian immigrants could not become naturalized; they could not become full members of the national community, even if they wanted to become citizens. ${ }^{68}$ Then World War II taught us the tragic lesson that, for those born here, even citizenship was not enough. The Nisei, second generation Japanese Americans and United States citizens by birth, were denied their place in the national community and were placed in internment camps.

These restrictions were based on a sense of who belonged in the national community. These restrictions also solidified or helped to construct the country's sense of the national. The stronger the sense of the national community, the more natural the restrictions were, and vice versa. ${ }^{69}$ It is in part through the figures of Asian immigrants and their descendants as perpetual internal foreigners that the national community has been able to identify itself. Without Asian Americans, the "real" Americans would not have known who they were.

James Baldwin makes a similar point in the inverse: "If I'm not who you say I am, then you're not who you think you are." Today, new social movements comprising Asian Americans, African Americans, Latina/os, Native Americans, women, and gays and lesbians are all resisting the dominant majoritarian constructions that have been imposed upon them. These subordinated, previously silenced groups are saying, "We're not who you say we are," thus destabilizing America's national identity. The result: crisis.

68. United States v. Thind, 261 U.S. 204 (1923) (denying naturalization rights to Asian Indian immigrants); Ozawa v. United States, 260 U.S. 178 (1922) (denying naturalization rights to Japanese immigrants). For an excellent recent discussion of these cases, see HANEY L6PEZ, supra note 31.

69. Cf. Keith Aoki, "Foreign-ness" \& Asian American Identities: Yellowface, Propaganda and Bifurcated Racial Stereotypes, 4 UCLA AsIAN PAC. AM. L.J. (forthcoming 1997) ("[E]verything they are, we are not, and vice versa.").

70. Interview with James Baldwin (CBS television broadcast, Oct. 1967), quoted in Adeno Addis, "Hell Man, They Did Invent Us:" The Mass Media, Law, and African Americans, 41 BuFr. L REv. 523, 528 (1993) (citation omitted). 


\section{National Identity Crisis and the Resultant Backlash}

Earlier, we stated that changes in demographics have created the specter of a coming majority of color. These changing demographics have created a national identity crisis which is evident in the debate over multiculturalism. Arthur Schlesinger, Jr., observes astutely:

A struggle to redefine the national identity is taking place ... in many arenas-in our politics, our voluntary organizations, our churches, our language - and in no arena more crucial than our system of education.... The debate about the curriculum is a debate about what it means to be an American. What is ultimately at stake is the shape of the American future. ${ }^{71}$

While we agree that the shape of the American future is at stake, we part company with his conclusion that "[t]he American synthesis has an inevitable Anglo-Saxon coloration" which must be preserved through proper education if we are to avoid "disintegration of the national community, apartheid, Balkanization, tribalization."72

Within this broader national identity crisis, Asian Americans present a special problem. On the one hand, we are constructed as a model minority, and certain discourses try to incorporate Asian Americaus into the American allegory of hard work and perseverance. ${ }^{73}$ Other racial minorities and poor Whites are scolded for not being more like Asian Americans. On the other hand, our purported successes are turned upon us and we are told that there are "too many" of us. ${ }^{74}$ We don't quite fit the mold of the Ainerican success story because we remain, on the surface, un-American. Our successes threaten the collapse of that dream for "real" Americans. At present, this tension is mediated through the technology of nativistic racism, which is used to manage the presence of Asian Americans in the national body.

For example, let us return to the story about the U.S. border guard. When the White man presented his state driver's license, he was immediately recognized as belonging to the national community. When one of

71. SCHLESINGER, supra note 2 .

72. Id. at 67. For a cogent critique of Schlesinger, see Stanley Fish, Bad Company, 56 Transition 60 (1992).

73. See, e.g., Success Story of One Minority Group in U.S., U.S. News \& WORLD REP., Dec. 26, 1966, at 73, reprinted in Roots: An Asian AMERICAN REAdEr 6 (Amy Tachiki et al. eds., 1971). For critiques of the Asian American model minority thesis, see Ronald T. TAKAKI, Strangers from a Different Shore: A History of Asian Americans (1989); Chang, supra note 5 , at 1258-65.

74. See, e.g., Selena Dong, Note, "Too Many Asians": The Challenge of Fighting Discrimination Against Asian-Americans and Preserving Affirmative Action, 47 SraN. L. Rev. 1027 (1995). 
the authors presented his state driver's license, he was recognized as foreign. He required further investigation. As such, his place (and that of others who look like him) in the national community is less certain.

This policing of the national community has repercussions beyond the geo-political border, because the border is imperfect. It does not operate perfectly in excluding that which does not belong. Some slip through, managing to escape detection. As a result, the geo-political border is supplemented by internal policing mechanisms, formal and informal.

Sometimes, the foreign element has to be isolated so that it can be monitored, controlled. The early Chinatowns, which were used to demonstrate the unwillingness of the Chinese to assimilate, were often the result of residential segregation. At other times, the foreign element has to be driven out, expelled for the good of society. In both cases, though, the foreign is seen as a threat, dangerous to peace and security. Anxiety over this threat becomes exacerbated during times of economic uncertainty. Efforts then are made to further restrict inembership in the national community.

Measures such as Proposition 187 target illegal immigrants, who are presented as the problem. They take jobs away from those who belong here. They use public services so that there is less for everyone else. Blaming illegal immigrants slides quickly into blaming all immigrants. The Federal Welfare Reform Act of 1996 allows states to cut off aid to even legal immigrants. ${ }^{75}$ Although these measures focus on immigration and citizenship status, problems arise, because that status is not evident from an individual's features. Foreign-ness then becomes a proxy for questionable immigration status. Foreign-ness triggers further scrutiny.

This presents a special problem for Asian Americans and Latina/os. Because of the construction of the national community as White and Black, Asian Americans and Latina/os are discursively produced as foreign. Foreign-ness is inscribed upon our bodies in such a way that Asian Americans and Latina/os carry a fignrative border with us. This fignrative border, in addition to confirming the belonging-ness of the "real" Americans, inarks Asian Americans and Latina/os as targets of nativistic racism. It renders us suspect, subject to the violence of heightened scrutiny at the border, in the workplace, in hospitals, and elsewhere.

75. See Bosniak, Membership, Equality, and the Difference that Alienage Makes, supra note 56, at $1050-51$ n.7. 
Then there is the different intrusion of physical violence. Nativistic racism directed against those of Asian descent in America has historically expressed itself in violent attacks. The killing of Vincent Chin in Detroit is one variation on this theme. ${ }^{76}$ Vincent Chin was a Chinese American killed in 1982 by Detroit autoworkers Ronald Ebens and Michael Nitz. According to one witness, Ebens said "that it was because of people like Chin-Ebens apparently mistook him for a Japanesethat he and his fellow employees were losing their jobs."77 Ebens and Nitz pleaded guilty to manslaughter and were given no prison time. Instead, they were each given three years probation and fines of $\$ 3,780 .^{78}$

Another variation on the theme of nativistic racism targeting Asian Americans is the killing of Navroze Mody. Mody was an Asian Indian who was beaten to death in 1987 in Jersey City by a gang of eleven youths. The gang did not harm Mody's White friend. No murder or bias charges were brought; three of the assailants were convicted of assault while one was convicted of aggravated assault. ${ }^{79}$ To understand the siguificance of this attack, it must be placed in context. At the time of the attack, Asian Indians were the fastest-growing immigrant group in New Jersey; many settled in Jersey City. Racially motivated hostilities increased with the growth of the Asian Indian community and the transformation of Jersey City as Asian Indians opened shops and restaurants. Earlier in the same month that Navroze Mody was killed, a Jersey City gang, called the Dotbusters (a reference to the bindi, the dot that Indian women often wear as a sigu of marital fidelity), had published a letter in the Jersey Journal saying that they "would 'go to any extreme' to drive Indians from Jersey City." Violence against the Indian community began the next day.

76. For an excellent in-depth analysis of the Vincent Chin case, see Paula C. Johnson, The Social Construction of Identity in Criminal Cases: Cinema Verite and the Pedagogy of Vincent Chin, 1 Mich. J. RACE \& L. 347 (1996); see also Robert S. Chang, Dreaming in Black and White: RacialSexual Policing in The Birth of a Nation, The Cheat, and Who Killed Vincent Chin?, 5 AsIAN LJ. (forthcoming 1998).

77. Sucheng Chan, Asian Americans: An Interpretive History 177 (1991). The men were indiscriminate in their use of epithets, also calling him a "Chink." AMERICAN CitizEnS For Justice, Confidential Report on the Vincent Chin Case to the U.S. Department of Justice, Civil Rights Division 3 (June 28, 1983) (copy on file with author).

78. U.S. Commission on Civil Rights, Civil Rights Issues Facing Asian Americans in THE 1990s, at 25 (1992).

79. See id. at 29.

80. Al Kamen, After Immigration, an Unexpected Fear: New Jersey's Indian Community is Terrorized By Racial Violence, WASH. Post, Nov. 16, 1992, at A1, A6. 
These recent events read in some ways like a page from the book of history. They resemble other racially motivated incidents of the past, such as what happened in 1877 in Chico, California. While attempting to burn down all of Chico's Chinatown, White arsonists murdered four Chinese by tying them up, dousing them with kerosene, and setting them on fire. The arsonists were members of a labor union associated with the Order of Caucasians, a White supremacist organization which was active throughout California. The Order of Caucasians blamed the Chinese for the economic woes suffered by all workers. ${ }^{81}$

The Chinese Massacre of 1885 also took place in the context of a struggling economy and a growing nativist movement. In Rock Springs, Wyoming, a mob of White miners, angered by the Chinese miners' refusal to join their strike (it should be remembered that unions did not permit Chinese members), killed twenty-eight Chinese laborers, wounded fifteen, and chased several hundred out of town. A grand jury failed to indict a single person. ${ }^{82}$

We tell these stories not to point out failures of justice but to show how violence operates to regulate boundaries. This violence is spurred on by certain narratives of America which permit and perhaps encourage the pathological impulse toward nativistic racism. This violence is not confined to the geo-political periphery; it may explode anywhere that there is a border (and remember: the border is everywhere). This has serious consequences for those who carry a figurative border on our bodies. Asian Americans and Latina/os, as perpetual internal foreigners, allow "real" Americans to reassure theinselves that the national community begins and ends with themselves, ensuring, at least momentarily, a stable notion of the national community and the fiction of a homogeneous American identity. The limitations of this nostalgic, fictional American identity are magnified when we examine Monterey Park, California, where there has been a large influx of capital, information, and persons. Monterey Park allows us to observe the interaction of national borders and the construction of racial subjects as community members negotiate electoral politics and coalition building.

81. See Chan, supra note 77, at 49.

82. See Paul Crane \& Alfred Larson, The Chinese Massacre, Annals of Wroming, Jan. 1940 , at $47,47-49$. 
III

\section{Global Economic Restructuring and the Political Economy of RACE IN MONTEREY PARK: RECEIVING THE INTER/NATIONAL}

\section{A. The Troubled Construction of Transcendent Racial Categories Within the Nation-State}

Centering the immigrant exposes the interaction among race, nation, and borders. There is an intimate connection between the creation and reinforcement of racial categories, the hardening of national borders, and various macro- and micro-phenomena occurring on the supraand sub-national levels. After briefly sketching these issues, we examine the relationship among them in the context of Monterey Park, California, a community that has experienced a large influx of immigrants. Because the effects of immigration are magnified in this case study, some difficult theoretical questions can be explored by focusing on demographic changes wrought by the immigrant.

While, at first glance, a homogenous American identity may be hypothecated and attain a momentary plausibility (even in the face of pervasive nativist racialized violence, occurring at many levels from the institutional to the individual), it is important to note that such a homogeneous American identity is internally unstable within U.S. borders. Such an "American" identity breaks down into a limited number of apparently unitary, but conceptually confused, racialized categories posited within the nation-state's borders (e.g., Black, White, Asian Pacific Islander, Hispanic, etc.) ${ }^{83}$ There is much temporal and spatial

83. See generally Race and Ethnic Standards for Federal Statistics and Administrative Reporting, 43 Fed. Reg. 19, 269 (1978) (creating four racial categories: (1) American Indian or Alaskan Native; (2) Asian or Pacific Islander; (3) Black; and (4) White; as well as an ethnic category: Hispanic); EsPIRITU, supra note 13, at 112-33 (1992); HigHAM, supra note 20; KARST, supra note 20; Henderson, supra note 20; Martin, supra note 20; Volpp, supra note 16; see also Steven A. Holmes, Census Sees A Profound Ethnic Shift in U.S.: By 2050, Non-Hispanic Whites Will Decline to a Slim Majority, N.Y. TMES, Mar. 14, 1996, at A8, which notes that

[b]y $2050, \ldots$ immigration and differences in birth rates, combined with an overall slowdown in growth of the country's population, will produce a United States in which 53 percent of the people will be non-Hispanic whites, down from 74 percent today. In contrast Hispanic people will make up 24.5 percent of the population, up from the current 10,2 percent, and Asians will make up 8.2 percent, an increase from the current 3.3 percent. The percentage of the black population will remain relatively stable, rising to about 13.6 by the year 2050 from the current 12 percent. . . Overall the [census] report suggests that the United States is experiencing one of the most dramatic shifts in its racial and ethnic makeup since the trade in slaves transformed the racial composition of the South and the waves of immigration from Eastern and Southern Europe in the late 19th and early 20th centuries gave an ethnic flavor to industrialized areas of the Northeast and Midwest. 
fluidity to these categories and they are, as we have pointed out, suffused to varying degrees with racialized "foreign-ness." 84

For example, on a temporal axis, Tomás Almaguer writes that in nineteenth-century California, Mexicans within the United States were classified as de facto Whites for a variety of reasons, whereas immigrant Chinese laborers were classified almost uniformly as non-White. ${ }^{85} \mathrm{~A}$ century later, we may be witnessing the racialization of the category "Hispanic" and the troublingly partial and contradictory deracialization of Asian Americans as the "model minority." On a spatial axis, consider the different constructions to which the term Latina/o might be susceptible in Puerto Rico, New York, Miami, San Diego or Highland Park, Illinois. Likewise, the construction of the category Asian American might differ greatly from Flushing, San Francisco, Los Angeles or Atlanta, Georgia. Frustratingly, our received racial categories on this level are both underinclusive and overinclusive. They are underinclusive, because, in many important ways, they are insensitive to the mnltiple factors that make racial formation a dynamic phenomenon with multiple spatial and temporal inputs. ${ }^{86}$ They are overinclusive, because the categorical net they cast encompasses too much, suppressing important distinctions within such broad categories. ${ }^{87}$

Did Navroze Mody's killers want to do him harm because he was Asian? Nonwhite? Foreign? All of the above? Similarly, because Vincent Chin's attackers were out to avenge themselves on Japan, did it matter that Vincent Chin was of Chinese descent?

Id.; see also Norimitsu Onishi, New Sense of Race Arises Among Asian Americans, N.Y. TimEs, May 30, 1996, at Al (describing the emergence of pan-ethnic consciousness evidenced by an increasing number of Asian American clubs on the East and West coasts).

84. See generally HANEY LóPEZ, supra note 31 .

85. See Tomás Almaguer, Racial Fault lines: The Historical Origins of White SuPREMACY IN CALIFORNIA 4-6 (1994) (exploring the origins of racial stratification in California).

86. See generally OMl \& WINANT, supra note 12, at 53-76 (discussing differential racialization).

87. See Gotanda, supra note 11, at 36-62 (discussing four senses of "race" in U.S. racial discourse: (1) status-race; (2) formal-race; (3) historical-race; and (4) culture-race).

Under the status-race approach, which assumes the subordinated status of Blacks, racial segregation by custom or statute reflects a 'common sense' understanding of the 'natural' racial hierarchy. In contrast, the formal-race, color-blind approach, assumes 'equal protection of the law' based on common 'citizenship'.... [ln] [h]istorical-race usage, racial categories describe relations of oppression and unequal power. Historical-race usage of Black does not have the same meaning as usage of white; Black is the reification of subordination; white is the reification of privilege and superordination. . . . Culture-race includes all aspects of culture, community, and consciousness.

Id. at $38,40,56$. 
Ideas of race and nation exist in a feedback loop, each reinforcing the other ${ }^{88}$ Domestic racial categories are assumed to be in force (and are institutionally enforced) uniformly within the geographic boundaries of the United States, in a transcendent fashion, i.e., we seem to assume that the category "Asian American" (or "Latina/o") remains a stable racial marker whether in Mobile, Alabama or Honolulu, Hawaii. ${ }^{89}$ The construction of transcendent racial categories within the fixed boundaries of a nation-state underwrites and strengthens (politically, legally, materially, etc.) those sovereign national boundaries, which in turn reinforces the salience of existing racial categories within those boundaries. ${ }^{90}$

This feedback loop to a great extent disguises and suppresses the existence of intimate and complex structural connections between macro-phenomena occurring on the trans- and supra-national levels ${ }^{91}$

88. See Constructions of Race, Place, and Nation (Peter Jackson \& Jan Penrose eds., 1994).

89. For an example of an aporia occurring at the intersection of race and nationality, consider the plight of more than 2,000 Japanese Latin Americans who were deported as "undesirable" and sent from their homes in Peru and other South American countries to the U.S. at the request of the U.S. government during World War II. These Latin Americans of Japanese descent were interned, along with over 100,000 Japanese Americans, in the infamous U.S. Relocation Camps. The U.S. government wanted to use the Japanese Latin Americans as possible exchange subjects for U.S. prisoners of war held by the Japanese. Following the end of World War II, some of the Japanese Latin Americans sought to return to their homes in South America, but were rebuffed for various reasons, chief among which was the fact that they had been deported in the first place. Some stayed in the U.S., but they were not given the reparations which were paid in the late 1980s and early 1990s to Japanese American internment camp survivors. In August 1996, the Japanese Latin Americans sued in federal district court in San Francisco for reparations for their intemment. In what coinplex ways might these Japanese Latin Americans be considered Latina/os or Asian Americans? See Manjusha P. Kulkani, Application of the Civil Liberties Act to Japanese Peruvians: Seeking Redress for Deportation and Internment Conducted by the United States Government During World War II, 5 B.U. PUB. INT. L.J. 309, 313 (1996); Maki Becker, Central Los Angeles Japanese Peruvians Launch Campaign for WWII Redress, L.A. TmES, Aug. 29, 1996, at A1; Tim Golden, Latins of Japanese Descent Seek Reparations, N.Y. TMES, Aug. 29, 1996, at A1.

90. See Etienne Balibar, Is There a "Neo-Racism"?, in RACE, NATION, Class, supra note 19 .

91. Prior to the passage of the 1965 lmmigration and Naturalization Act, Asian immigrants had been uniquely singled out for exclusion. However, after 1965, Asian immigration occurred against a backdrop of regional economic integration in the Pacific Basin characterized by large-scale growth in trade relations, capital shifts and labor flows. "Immigration, trade, investment, economic aid, political and military involvement all go hand in hand." THE NEw Asian lMmigration IN LOS ANgeles aNd Global Restructuring viii (Paul Ong et al. eds., 1994) [hereinafter New AsIaN IMMIGRATION].

Some of these macro phenomena involve wars, trade disputes, International Monetary Fund ("IMF") and World Bank investment decisions affecting development. See Tariq Banuri, Development and the Politics of Knowledge: A Critical Interpretation of the Social Role of Modemization Theories in the Development of the Third World, in DomNating KNowledge: Development, Culture, ANd Resistance 29 (Frederique A. Marglin \& Stephen A. Marglin eds., 
and micro-level phenomena occurring on the sub-national, regional, county, city or even neighborhood levels. ${ }^{92}$ For example, wars, trade disputes, dynamic transnational labor and capital flows affect patterns of investment and disinvestment in American cities ranging from gentrification to the creation of informal economies of sweatshops and pieceand home-work. The border does not end or begin at the perimeter of the nation-state, but occurs at encounter zones where immigrants pass through these different levels of boundaries where global economic restructuring hurls immigrants into labor oppression (including state, county or municipal borders as well as racial boundaries) within the nation-state. ${ }^{93}$

1990) (noting how modernization/development in the Third World has been extremely uneven, producing heightened levels of unemployment and immiseration with significant "push" effects for immigration). Other phenomena include changing dynamics of transnational capital flows, flows of labor within and across national borders, and distribution of environmental risks and burdens. See Peter Dicken, Global Shift: Industrial Change in a TUrbulent World (1986) (examining multiple levels on which globalization occurred in the 1980s); RoLAND RoBERTSON, Globalization: Social Theory and Global Culture (1992); Banuri, supra, at 30-31 (noting an increasing association of development with ecological disasters); Robert W. Cox, Global Restructuring: Making Sense of the Changing International Political Economy, in POLITICAL Economy and The Changing Global ORder 45 (Richard Stubbs \& Geoffrey R.D. Underhill eds., 1994) (critiquing effects of globalization through the lens of political economy); William Plummer, The Big Push: Emigration in an Age of Environmental Catastrophe, 4 1ND. J. GloBAL LEG. STUD. 231 (1996) (describing the links between development policies that produce ecological and social shifts that work to drive people, particularly poor people, out of the developing world as environmental refugees); David Slater, Contesting Visions of the Global: The Geopolitics of Theory and North-South Relations, BEYOND LAW, Dec. 1994, at 97, 108. ("[W] ithin the poorer nation-states of the world, the hegemony of the IMF and the World Bank, and the privatization and liberalization they legitimize incorporates political meehanisms for representing the interests of the industrialized West and their transnational corporations.").

92. Such micro-level effects include phenomena such as patterns of disinvestmcnt, gentriflcation, and White flight from urban areas producing race-based hypersegregation. See generally Daniel R. Fusfeld \& Timothy Bates, The Political Economy of the Urban Ghetto (1984); Douglas S. Massey \& Nancy A. Denton, AMERican Apartheid: SEgRegation aND tHE MAKING of the UNDERclass (1993) (describing the high degree of spatial segregation based on race that pervades America); NeIL SMITh, THE NEW URBan Frontier: GENTRIFICATION AND THE REvanchist CITY (1996) (looking at the close ties between macrocconomic forces such as interest rates and global investment and neighborhood gentrification); see also Rosemary J. Coombe, The Cultural Life of Things: Anthropologieal Approaches to Law and Society in the Conditions of Globalization, 10 AM. U.J. INT'L L \& POL'Y 791 (1995) (examining the creation of an international informal labor cconomy of illegal sweatshops, piece and homework regimes with substandard conditions and pay, etc., organized along strongly racialized and gendered lines); Laura Ho et al., (Dis)Assembling Rights of Women Workers Along the Global Assembly Line: Human Rights and the Garment Industry, 31 HaRv. C.R.-C.L. L. REv. 383 (1996).

93. Mare Cooper describes the role of immigrants in the meatpacking industry:

Putting the lie to the conventional wisdom undergirding our immigration policy, the arrival of these workers en masse is neither serendipitous nor the product of cunning smugglers. Rather, it is the direct result of a conscious survival strategy undertaken by a key U.S. industry, a plan developed and fully implemented only in the past few years. . . . Beef, pork 
Macro- and micro-phenomena appear to be superficially unconnected. Their dynamic linkage is disguised in part by an over-emphasis on the concept of the sovereign nation-state that hides the interrelationship between macro and micro. As people are pushed and pulled by various macro- and micro-forces, the boundaries of the sovereign nation-state impede their migration, creating a conceptual and legal inside and outside. This allows, for example, transcendental domestic racial tropes to be inscribed upon those who would enter, as well as providing a rationale for keeping them out. ${ }^{94}$

Centering the immigrant exposes relationships among macro- and micro-phenomena, that are traditionally obscured by the pervasive construct of the sovereign nation-state. For example, U.S. immigration discourse tends to look at immigration on the level of a particular individual's decision to immigrate to the U.S. in search of greater economic opportunity. However, Saskia Sassen points out that

[s]uch a view puts all the responsibility for immigration on the immigrants. Commentators who speak of an immigrant "influx" or "invasion" treat the receiving country as passive:

and poultry packers have been aggressively recruiting the most vulnerable of foreign workers to relocate to the U.S. plains in exchange for \$6-an-hour jobs in the country's most dangerous industry. Since permanence is hardly a requirement for these jobs, the concepts of promotion and significant salary increase have as much as disappeared. That as many as half of these new immigrants lack legal residence seems no obstacle to an industry now thriving on a docile, disempowered work force with an astronomical turnover. Staggering illness and injury rates-36 per 100 workers in meat-and stress caused by difficult, repetitive work often means employment for just a few months before a worker quits or the company forces him/her off the job.

Marc Cooper, The Heartland's Raw Deal: How Meatpacking is Creating a New Immigration Underclass, Nation, Feb. 3, 1997, at 11.

94. As Howard Winant writes:

Race provides a key cultural marker, a eentral signifier in the reproduction and expression of identity, collectivity, language and agency itself. Race generates an "inside" and an "outside" of society, and mediates the unclear borders between these zones: all social space, from the territory of the intrapsychic to that of the U.S. "national character" is fair ground for racial dilemmas, doubts, fears and desires.

Howard Winant, Racial Conditions: Theories, Politics, Comparisons 30 (1994).

Once immigrants are racialized, the idea of isolation becomes the required precondition for further limits on immigration:

In northern San Diego and southern Orange Counties-Southern California's 95 percent white "futuropolis" of affluent planned communities... [and] hysterical homeowners" associations, supported by local businessmen, have begun to wage war against the very immigrant labor upon which their master-race lifestyles depend .... Since there is virtually no lower-income housing between the Santa Ana barrio [south of L.A.] and East San Diego (a ninety-mile distance) thousands of day-laborers and their families-Spanish-speaking Okies of the 1980s-are forced to live furtively in hillside dugouts and impromptu brush camps, often within sight of million-dollar tract houses whose owners now want the "immigrant blight" removed.

Mike Davis, CtTy of Quartz: Excavating the Future in Los Angeles 208-09 (1990). 
immigration is unconnected to the past or current actions of receiving countries, and immigration policy is portrayed as more or less benevolent toward immigrants. Absent is any awareness that the international activities of governments or firms of countries receiving immigrants may have contributed to the formation of economic links with emigration countries, links that may invite the moveinent of people as well as capital. ${ }^{95}$

A paradoxical question must be faced: As communications and transportation technologies render traditionally conceived nation-state boundaries increasingly porous to growing flows of information, goods and capital, why are the borders of the sovereign nation-state being reasserted in the strongest way to exclude or limit flows and migrations of persons, frequently on a strongly racialized basis $?^{96}$

While the full answer to this question lies beyond the scope of this piece, we believe that the beginnings of an answer may be found in examining gaps arising at the intersection of domestic understandings of race and inter/national factors affecting immigration. One such site where the global, national and regional have met (soine might say collided) is Southern California from the 1960s to the 1990s. The specific intersection we examine is Monterey Park, California in the 1990s, located eight miles east of Los Angeles in the San Gabriel Valley. Monterey Park has been called "The First Suburban Chinatown."97

95. Saskia Sassen, Losing Control?: Sovereignty in an Age of Globalization 84 (1996) [hereinafter SAsSEN, LOSing Control]. See generally SaSkia Sassen, The Mobility of Labor and Capital: A Study in International InVestment and Labor Flow (1988) [hereinafter SASSEN, MOBIITY OF LABOR AND CAPital].

96. See generally ArJun Appadurai, Modernity at large: Cultural Dimensions of GLOBALIzATION 158 (1996) (examining the rise and intersection of new linds of nationalisms with constructions of race and gender identities); SASSEN, LOSING CONTROL, supra note 95; Stuart Hall, The Global and the Local: Globalization and Ethnicity, in Culture, Globalization, and the WORLD-SYSTEM: CONTEMPORARY CONDITIONS FOR THE REPRESENTATION OF IDENTITY (Anthony D. King ed., 199I)(describing the problematic relation in terms of representation of increasingly global economic production and localized racial, ethnic, religious and gender identities).

97. Tmothy P. Fong, The First Suburban Chinatown: The Remaking of Monterey Park, California (1994). 


\section{B. Monterey Park: A Locus of the Inter/National}

From 1960 to 1990 , Monterey Park underwent dramatic changes in the racial composition of its residents, as the following chart demonstrates:

\section{ETHNIC COMPOSITION OF MONTEREY PARK, 1960-199098}

PERCENTAGE OF CITY POPULATION

\begin{tabular}{|l|l|l|l|l|}
\hline Ethnicity & $\mathbf{1 9 6 0}$ & $\mathbf{1 9 7 0}$ & $\mathbf{1 9 8 0}$ & $\mathbf{1 9 9 0}$ \\
\hline African American & 0.003 & 0.2 & 1.2 & 0.6 \\
\hline Anglo & 85.4 & 50.5 & 25.0 & 11.7 \\
\hline Asian/Pacific Islander & 2.9 & 15.0 & 35.0 & 57.5 \\
\hline Latino & 11.6 & 34.0 & 38.8 & 29.6 \\
\hline
\end{tabular}

Over the course of 30 years, Monterey Park shifted from an over $85 \%$ White suburb to $57.5 \%$ Asian/Pacific Islander. Additionally, the percentage of Latino residents climbed from $11 \%$ in 1960 to almost $30 \%$ in 1990 . Note further that the percentage of African Americans remained at or below $1 \%$. These numbers have significance for what they represent with respect to the global, the national and the local.

Many of the new Chinese immigrants to Monterey Park differed from earlier Asian immigrants to the United States. ${ }^{99}$ Ong, Bonacich and Cheng write that:

98. Leland T. Saito \& John Horton, The New Chinese Immigration and the Rise of Asian American Politics in Monterey Park, California, in New AsIan IMmigration, supra note 91, at 234. Note that Saito \& Horton use the term ethnicity, and that they furthermore use the term AngIo as roughly equivalent to the category "White." For reasons we will discuss, in our analysis there is considerable overlap between the way that we use the term "race" and the way that "ethnicity" has been used by Saito \& Horton. Indeed, if one looks at the categories comprising Saito's and Horton's chart, it is interesting that African American is described as an "ethnicity."

99. For a more detailed sense of how earlier immigration intersects with newer immigration, see John Horton, The Chinese Suburban Immigration and Political Diversity in Monterey Park, California, Soc. JusT., Fall 1996, at 100, 100-01.

By 1970, Monterey Park had become a middle-class home for Mexican Americans from nearby working-class East Los Angeles and for Japanese Americans ... from enclaves in the east and west sides of L.A. and from regions of forced wartime internment and exile. There was also a migration of Chinese from the old Chinatown located just west of Monterey Park... [which] was the combined result of postwar economic mobility and the legal and informal erosion of discrimination in housing... In 1980 the city was almost evenly divided among Anglos (25\%), Latinos (39\%), and Asian Americans (35\%). The small population of African Americans made up just over one percent. . . By 1990 Asian residents had become the majority with about $60 \%$ of the population, while Anglos declined sharply to $12 \%$ and Latinos declined slightly to $31 \%$ of the total. The composition of the Asian population also shifted, with the younger Chinese newcomers now decisively replacing older native-born Japanese Americans as the largest Asian group. 
[Many of the new immigrants] are from urban, educated, middle-class backgrounds ... [and are] professionals, managers and entrepreneurs.

... Some of the shift toward higher-educated, professional immigrants is a product of U.S. Immigration law, which gives preference to highly trained people.... [However,] not all the new Asian immigrants are middle-class professionals and managers. Indeed, Asian communities often reveal a class polarization. At one end are the well-off groups ... and at the other are people working in low-skilled, minimum-wage, service-sector and manufacturing jobs, or who are unemployed. Although the median income of several of the Asian communities is relatively high, Asians suffer twice the poverty rate of the dominant society. ${ }^{100}$

Monterey Park not only experienced an influx of middle-class ethnic Chinese immigrants in the 1970s and 1980s, but also was a destination for foreign- and native-born Latina/os. Mike Davis writes that during the 1980s, the San Gabriel Valley

ha[d] become a major destination for upwardly mobile Chicanos leaving East L.A.... [T] he quarter-million Chicanos (primarily blue-collar craftsmen and professionals) [were] perceived primarily as a political threat to entrenched Anglo power structures, the 150,000 Chinese (businessmen and developers as well as professionals and workers) [were] resented for their alleged role in overdeveloping and physically degrading whole communities. ${ }^{101}$

Davis' quote captures some of the rich interplay of factors at work in Monterey Park: a formerly largely White/Anglo middle-class community ${ }^{102}$ shifting to an unstable mix of Asian, Latina/o and White by $1980,{ }^{103}$ then shifting further to a majority of Asian and Latina/o with a small White/Anglo minority and a minuscule African American presence. Furthermore, Davis introduces an element of class analysis into the picture-what are we to make of the class differences between upwardly mobile working-class Chicanos and middle- and upper-class

100. NEW ASIAN IMMIGRATION, supra note 91, at 4.

101. DAvis, supra note 94, at 206-07; see also Rodolfo ACUÑa, ANYTHing But MEXICAN: Chicanos in Contemporary Los ANgeles (1996).

102. For example, Timothy Fong points out that during the first half of the twentieth century, Monterey Park (which was then known as Ramona Acres) was one of the Whitest spots in Southern California's White spots, and, in 1924, was the host city to a 25,000 person Ku Klux Klan rally held to initiate 500 new members. See FoNG, supra note 97, at 18. In 1928, Peter Snyder, a developer, built Midwich View Estates in Ramona Hills, which was to "exclude those whose blood is not wholly of the Caucasian race." Id. at 18-20.

I03. See Horton, supra note 99, at 100-01. 
Chinese entrepreneurs? Monterey Park asks us what it means when inter/national diaspora capital meets U.S. race relations on the charged field of class, race relations and political representation. ${ }^{104}$

Monterey Park is significant for a number of reasons. First, many of the demographic shifts in Monterey Park are linked to larger global phenomena that have been proceeding apace for the past thirty years. ${ }^{105}$ Many of these phenomena may be thought of as part of the processes associated with rapid global economic restructuring, ${ }^{106}$ much of it driven by the expanding Pacific Basin economy, but which has significant effects within the United States. As the Pacific Basin region experiences rapidly growing trade relations, increasingly two-way flows of capital and investment, and related military and political commitments, the flow of persons across borders is related to and is partly constitutive of them. Analytically, "immigration, trade, investment, economic aid, political and military involvement all go hand in hand."107

Second, as Leland Saito and John Horton have written:

Monterey Park is an especially significant site for studying the impact of post-1965 Asian immigration on local politics. $[\Pi \mathrm{t}$ is the only city in the United States, outside Hawaii, that has a majority Asian population (57\% in 1990).... [Additionally,] Monterey Park is a regional locus of political activism. ... AntiAsian activities, demographic changes and the need for Asian

104. See New Asian Immigration, supra note 91, at 31 .

[E]conomic inequality in Los Angeles is related to the growing class-and-race polarization. ... [T] presence of large numbers of immigrants redefines the process into a multiracial phenomenon. NonHispanic whites (commonly referred to as Anglos) occupy the top tier, and African Americans the bottom tier, with Latino immigrants generally performing the role of low-wage labor.

Id.

105. See New Asian Immigration, supra note 91, at 5-8.

106. "Economic restructuring" refers to the process that occurs in a capitalist system when there is an economic crisis characterized by

large-scale and pervasive dislocation of capital and labor.... [E]xisting industries and workers are cast aside permanently, rather than being temporarily underused and unemployed, as during a recession. ... [E]conomic changes overrun the social and political structures and the prevailing ideology that had previously stabilized and supported economic relationships.... [I]t is [then] necessary to construct a new set of structures and to adopt another dominant ideology. [I]ncongruities between emerging economic realities and preexisting societal structures force a wholesale redefinition of industrial organization and employer-worker relationships.

New Asian Immigration, supra note 91, at 6.

107. New Asian Immigration, supra note 91, at viii; see also Horton, supra note 99, at 110 (suggesting that a politics of inclusion is the only viable alternative to the failed attempts of national governments to halt immigration). 
American political representation have combined to make Monterey Park a focal point for Asian American politics in the Los Angeles area ... [for those wishing to support] Asian American representation within a diverse, pluralistic society with a multicultural rather than Eurocentric orientation. ${ }^{108}$

Third, Monterey Park may be viewed, both temporally and geographically, against the backdrop of the "[i]nterethnic struggle [that] reached a high point following the acquittal of the four Los Angeles police officers accused of using violent force against Rodney King.... Following the verdict, hundreds of businesses owned by Koreans and other ethnic groups were looted and burned down by African Americans and Latinos." 109 While the 1992 uprising occurred within Los Angeles, Monterey Park is located in a racially charged region on several levels: (1) it is proximate to the U.S./Mexico border, and undocumented Latina/o workers have been increasingly racialized in political rhetoric and media representations; (2) Southern California in general is one of the most racially segregated areas in the U.S. (with the relevant racial lines often strikingly contiguous with municipal borders); and, (3) Los Angeles is a major site of Asian immigration, entailing racialization of new immigrants into the pre-existing U.S. racial structure. The fact that the San Gabriel Valley and Monterey Park in particular were virtually untouched by the 1992 uprising suggests both the depth of the racial/spatial concentration occurring in areas like South Central, but also the advantages to outlying communities of such segregation. ${ }^{110}$

108. Saito \& Horton, supra note 98 , at 233.

109. Leland T. Saito, Asian Americans and Latinos in San Gabriel Valley, California: Interethnic Political Cooperation and Redistricting 1990-92, in LOS ANGELES-STRUGgles TOWARD Multiethinic Community: Asian american, African American and Latino Perspectives 55 (Edward T. Chang \& Russell C. Leong eds., 1994) [hereinafter LOS ANGELES].

110. See id. at 66 .

Unlike the conditions in Los Angeles that sparked the events following the Rodney King decision, such as class divisions following ethnic lines, an educational system in crisis, high unemployment, few services, and deteriorating housing stock, the San Gabriel Valley had a significant middle class population.... [and] a number of Latino and Asian American individuals and organizations ... that had a history of working together.

Major differences between Los Angeles and the San Gabriel Valley ... cxplain why [multiracial/ethnic] agreement was reached in one place but not the other. First, the Asian American population mix in downtown was much more complex, with well developed Japanese, Chinese, Korean and Filipino communities as compared to the San Gabriel Valley which was dominated by Chinese and Japanese Americans.... [Also] the San Gabriel Valley Asian American population was more experienced politically because of its longer history of working on the campaigns of local Asian American candidates.... Second the downtown Asian American and Latino populations were spread out over a much larger area.... Third, the overall demographic mix [of downtown L.A.] vas more complicated with a large population of African Americans who were nearly absent (about 1 percent) in the San Gabriel Valley. This required taking into consideration the political rights of another 
Monterey Park thus raises significant questions about interethnic agency and responsibility as between different groups that have been racialized within the U.S. racial hierarchy as "non-white."111 The fact that there have been affirmative, although fragile, relationships and accommodations reached between Asian American and Latina/o organizations regarding redistricting and reapportionment following the 1990 U.S. census raises tantalizing questions about the limits of interracial and interethnic cooperation. ${ }^{112}$

\section{Representing the Immigrant(s): Latina/o and Asian American Politics in Monterey Park}

This Section examines the difficult problem of redistricting in a racialized space, first on a theoretical level, and then on a political level by analyzimg the efforts of an Asian American and Latina/o coalition faced with these issues in Monterey Park. The influx of Asian immigrants to Monterey Park affected local politics in a way that highlights connections between race and borders, albeit the borders of local government and legislatively drawn electoral districts. In the area of redistricting, the question of boundaries arises on an explicitly local level. We no longer focus on the national border, but on drawing borders that determine representation in the polity, as well as external borders between different racial/ethnic groups and internal borders within such groups. Whether it be on the local, state or national levels, the borders and boundaries that set the terms for political representation are crucial.

group, making the process much more complex. Fourth, downtown Los Angeles contained some of the most expensive real estate in the state, making it the site of much larger political battles than in the San Gabriel Valley.

Id. Cf. Lisa C. Ikemoto, Traces of the Master Narrative in the Story of African American/Korean American Conflict: How We Constructed "Los Angeles," 66 S. CAL. L. Rev. 1581 (1993); Reginald L. Robinson, "The Other Against Itself": Deconstructing the Violent Discourse Between Korean and African Americans, 67 S. CAL. L. REv. 15 (1993). See also Bill Ong Hing, Beyond the Rhetoric of Assimilation and Cultural Pluralism: Addressing the Tension of Separatism and Conflict in an Immigration-Driven Multicultural Society, 81 CALIF. L. REv. 863 (1993).

111. Eric K. Yamamoto, Rethinking Alliances: Agency, Responsibility and Interracial Justice, 3 Asian PaC. AM. L.J. 33 (1995); see also Lawrence Bobo, The Color Line, the Dilemma, and the Dream: Racial Attitudes and Relations at the Close of the 20th Century 42 (Feb. 23, 1995) (unpublished manuscript, on file with the author) ("We stand at a moment of great ambiguity, uncertainty and potentially momentous change in race relations.... The present is a time of deeply contradictory trends, not one of unequivocal backlash and polarization. Positive changes in racial attitudes and relations do not simply happen. They are made, in both intended and unintended vays.").

112. See generally ACUÑA, supra note 101, at 132 (describing the wary compromise reached by Latina/os and Asian Americans in the San Gabriel Valley); Saito, supra note 109, at 57-58; Yamamoto, supra note 111. 


\section{Mimesis and Representational Politics}

Theories of political representation have received a great deal of attention in recent years. Jerry Frug, ${ }^{113}$ Richard Thompson Ford, ${ }^{114}$ Lani Guinier, ${ }^{115}$ and John Calmore ${ }^{116}$ have investigated the consequences that a more sophisticated attitude toward electoral representation has on political theory, local government law, voting rights, redistricting and housing policy. ${ }^{117}$ This more sophisticated attitude involves, in part, understanding the complexity, on many levels, of the idea of "representation."

Political representation has both mimetic and semiotic components. ${ }^{118}$ Traditionally, political representation (i.e., a state's congressional delegation) is thought of as being "representative" of a state's body politic in toto. However, consider a hypothetical governmental unit, such as a state, consisting of 50\% males and 50\% females, and $60 \%$ Whites, 20\% African Americans, 10\% Latina/os, and 10\% Asian Americans. Under traditional U.S. voting rights law, this hypothetical state is likely to have a congressional delegation that is $100 \%$ White and male. The descriptive claim that the voting process is mimetic, or has a one-to-one correspondence to the polity, is incomplete at best and unrepresentative in troubling ways. ${ }^{19}$

113. See Jerry Frug, Decentering Decentralization, 60 U. Chr. L. Rev. 253 (1993); Jerry Frug, The Geography of Community, 48 StaN. L. REv. 1047 (1996) [hereinafter Frug, The Geography of Community].

114. See Richard T. Ford, The Boundaries of Race: Political Geography in Legal Analysis, 107 HARV. L. REv. 1841, 1908-09 (1994).

115. See Lani Guinier, The Tyranny of the Majority: Fundamental Fairness in Representative Democracy (1994); Lani Guinier, The Supreme Court 1993 Term: (E)Racing Democracy: The Voting Rights Cases, 108 HaRv. L. REv. 109 (1994).

116. See John O. Calmore, Racialized Space and the Culture of Segregation: "Hewing a Stone of Hope From a Mountain of Despair," 143 U. PA. L. REv. 1233 (1995); John O. Calmore, Spatial Equality and the Kerner Commission Report: A Back-to-the-Future Essay, 71 N.C. L. REv. 1487 (1993).

117. See, e.g., MASSEY \& DENTON, supra note 92 (describing links between spatial isolation and political disenfranchisement); Richard Briffault, Race and Representation After Miller v. Johnson, 1995 U. ChI. Legal F. 23 (1995) (exploring further implications of Shaw v. Reno with respect to redistricting); Lisa A. Kelly, Race and Place: Geographic and Transcendent Community in the PostShaw Era, 49 VAND. L. REv. 227 (1996) (critiquing the Supreme Court's post-Shaw v. Reno Voting Rights Act jurisprudence because it ignores the reality and effects of racially segregated space); George S. Swan, The Political Economy of American "Apartheid": Shaw v. Reno, 11 T.M. CoolEY L REv. 1 (1994) (discussing connections between segregation and political representation).

118. See Hanna Fenichel Pitkin, The Concept of Representation (1967) (analyzing the various senses of the concept of representation in European and American political theory).

119. See Ford, supra note 114, at 1908-09; Frug, Decentering Decentralization, supra note 113; Guinier, supra note 115 . 
However, the normative question of whether and to what degree mimesis is normatively appropriate is a separate question. The notion that political representation has, or should have, a strong mimetic component, at least with regard to race, is contradicted by the post-Shaw $v$. Reno voting rights cases. ${ }^{120}$ The one-person-one-vote claim of mimetic representation has rhetorical appeal because of its apparent "neutrality" and seeming "natural-ness"-voting results acquire a "found" aspect, as though they were just a snapshot of the polity on a particular day, that the will of the electorate was merely discovered and not invented in important ways. However, photographs are not mere factual recordings, but comprise a number of complex and intertwined decisions about framing, depth of field, exposure, composition, lighting, positioning, etc. Likewise the "snapshot" of the polity comprises a number of complex (and politically and racially charged) decisions which are concealed by claims of mimesis. ${ }^{21}$ There is no neutral "Eye of God" point of view from which to decide.

The idea that all voting systems have a strong symbolic, or semiotic, ${ }^{122}$ component exposes the "cooked" or "invented, not found"

120. See, e.g., Bush v. Vera, 116 S. Ct. 1941 (1996); Shaw v. Hunt, 116 S. Ct. 1894 (1996); Miller v. Johnson, 515 U.S. 900 (1995); Shaw v. Reno, 509 U.S. 630 (1993) (each striking down districts drawn by state legislatures following the 1990 census on the grounds that the redrawn districts impermissibly had taken racial composition into account); see also Epps, supra note 11 (critiquing the emerging "colorblind" jurisprudence represented by Shaw v. Reno); Pamela S. Karlan \& Daryl J. Levinson, Why Voting is Different, 84 CaLIF. L. REv. 1201 (1996) (arguing against application of a "colorblind" norm in the context of voting because of the strong remedial function race-conscious redistricting may have); Pamela S. Karlan, Maps and Misreadings: The Role of Geographic Compactness in Racial Vote Dilution Litigation, 24 HARv. C.R.-C.L. L. Rev. 173 (1989) (beginning to explore, pre-Shaw, the consequences of racialized space in the context of Section 2 of the Voting Rights Act of 1965); Kelly, supra note 117 (critiquing the Supreme Court's post-Shaw v. Reno Voting Rights Act jurisprudence, because it iguores the reality and effects of racially segregated space); Daniel D. Polsby and Robert D. Popper, Ugly: An Inquiry into the Problem of Racial Gerrymandering Under the Voting Rights Act, 92 MiCH. L. REv. 652 (1993) (discussing racial gerrymandering after Shaw v. Reno).

121. See Thomas C. Heller, Structuralism and Critique, 36 StAN. L. REv. 127, 134 (1984) (describing a mimetic view of language: "Language was not understood to create meaning, but rather to operate as a tool to uncover and manipulate a concealed, but already known or knowable, order. The content of this order was neither altered by, nor contingent upon, the mediation of the encounter with language itself.").

122. Id. at 141-42 (describing a semiotic vision of language: "Meaning ... arises solely from formal relations between signs and not directly from any substance in the sigus themselves ... [originating] in the discovery of similarity and difference within a system of discrete linguistic units."). See also Gary Peller, The Metaphysics of American Law, 73 CaLIF. L. Rev. 1151, 1173 (1984).

[R]epresentational structures can never be conclusively determined; this relational meaning depends on representational practice in which they are found. Any description of the representational structure within which meaning is generated is merely a representation of 
nature of voting districts. This notion then confronts decisionmakers with difficult (and ironically, political, in the broadest, as well as the most pejorative, sense of the word) choices involving what kinds of representation can be implemented, taking factors sucl as race and economic class into account-or not_and including other forms of voting, such as cumulative voting. One faces the paradoxical idea that, in order to get closer to mimesis (if it has been decided that is what one indeed wishes to do), one first needs to confront squarely the strong semioticand undeniably political, in its strongest sense-nature of redistricting and gerrymandering. Representation, racial and otherwise, has multiple and contradictory meanings, including: representation on a racial or other basis that is consistent with oftentimes-problematic census (which may exhibit a tendency to undercount minority populations) and other demographic data; representation that advocates on behalf of and promotes the expressed needs or agenda of a minority community within a district by a person who may or may not be a member of the particular community; or, as is more often the case, a hybrid representation including aspects of both demographic and agenda representation. ${ }^{123}$

As Richard Ford has pointed out, it is crucial to note the odd and disturbing disjuncture between post-Shaw voting rights cases that mandate "colorblindness" on the part of legislatures engaged in creating electoral districts and the seeming judicial deference to, and indeed endorsement of, municipal sovereignty with regard to local goveruments that ratify and reproduce strongly racially segregated residential spaces via zoning and other policies as well as "private" real estate markets structured and underwritten by such rules and policies. ${ }^{124}$ These spaces are often racially segregated along a suburban/urban axis. Monterey

\footnotetext{
the structure according to the language of the interpreter, the way that the interpreter Id. distinguishes relevance from irrelevance.

123. See generally Kelly, supra note 117 (discussing types of political representation in the voting context).

124. See Ford, The Boundaries of Race, supra note 114; Massey \& Denton, AMERICAN APARTHEID, supra note 92. For additional works that examine the racial and other politics of municipal incorporation and local government sovereignty, see also KENNETH T. JACKSON, Crabgrass Frontier: The suburbanization of the United States (1985); Evan McKenzie, Privatopia: Homeowner Associations and the Rise of Residential Private Government (1994); Gary Miller, Cities by Contract: The Politics of Munictpal Incorporation (1981); Jon C. Teaford, City and Suburb: The Political fragmentation of Metropolitan America (1981); Jon C. Teaford, Post-Suburbia: Government and Politics in Edge Cities (1996); Marc Weiss, The Rise of the Community Bullders: The American Real Estate Industry and URBan LANd Use Planning (1987); Frug, The Geography of Community, supra note 113.
} 
Park is interesting precisely because it challenges us to rethink what the color-line means both in regard to patterns of racial segregation and what electoral redistricting means in a multiracial context.

Issues surrounding pan-ethnicity in the context of Monterey Park approach these questions. ${ }^{125}$ Monterey Park poses the problem of political representation on at least two levels: (1) inter-ethnic/racial political organization between different communities and groups of color, such as coalitions between Asian American groups and Latina/o groups; and, (2) intra-ethnic/racial political organization as between different groups of Asian Americans along lines of generational arrival in the United States and the related level of nationality/ethnicity, e.g., Japanese American, Korean American, Chinese American, etc.

We will explore these two levels, inter-group and intra-group, by looking first at conflicts and cooperation between Latina/o and Asian American groups over redistricting in the California legislature after the 1990 census. Then we will examine intra-group tensions in the context of conflict and cooperation between native-born Asian Americans and newer, ethnic-Chinese immigrants.

\section{Redistricting in Monterey Park}

The minoritization of Whites in Monterey Park from 1960 to 1990 created inter-group tensions by transforming slow-growth ${ }^{126}$ and language rights ${ }^{127}$ concerns into issues with an explicitly anti-Asian edge. Monterey Park's phenomenal racial and ethnic restructuring beginning in the 1970s "produced a nativist backlash in the form of the RAMP (the Residents Association of Monterey Park) whose self-declared aim

125. For an excellent review of pan-ethnicity in the Asian American context, see EsplRIru, supra note 13 (1992); FoNG, supra note 97, at 138-56; Leland T. Saito \& John Horton, supra note 98 , at 233; Saito, supra note 109, at 55.

126. See DAv1s, supra note 94 , at 159 ("Slow growth ... is about homeowner control of land use and ... [is] the latest incarnation of a middle-class political subjectivity that fitfully constitutes and reconstitutes itself every few years around defense of household equity and residential privilege."); Horton, supra note 99, at 101 ("The city looks unfinished, caught between a Middle America of tranquil parks, tree-lined streets, and modest houses, and the encroaching restaurants, banks, supermarkets, mini-malls, condominiums, and the traffic of a Chinese boom town.").

127. See Fong, supra note 97, at 110,114; see also Heinz KLOSs, The AMERICAN BiLINGual Tradition (1977); Shirley Brice Heath, English in Our Language Heritage, in Language in the USA (Charles A. Ferguson et al. eds., 1980); Grace A. Pasigan, Sign Language: Colonialism and the Battle over Text, 17 LoyolA ENT. L.J. 625 (1997); Jay Carney, English Spoken Here, O.K.?: A California Crusade to Stamp Out Bilingualism, Time MAGazine, Aug. 25, 1986, at 27 ("A cultural cross fire over language-English vs. Chinese-has erupted in Monterey Park, with one side seeking to make English the city's official language and the other hurling charges of racism and xenophobia."). 
[was] slow growth, particularly the restriction of new multiple-use and commercial construction." 128 Because most of the real estate developers in Monterey Park that RAMP opposed were recent ethnic-Chinese immigrants, "RAMP ... invariably assumed the alter-ego of being the main opposition to 'further Chinese take-over'."129 During the 1986 city council elections, RAMP-sponsored candidates defeated "moderate ethnic harmonizers (two Latinos and a Chinese-American)," in part due to the fact that "the city's white minority was still a larger registered voting block than the new Chinese majority."130 After control of the city council shifted,

[t]he struggle over land-use control quickly became a fight over the "very definition of what constitutes an American community... when the City Council adopted an ordinance requiring Chinese businesses to include English translations on their signage." ... Monterey Park's slow-growth Know-Nothingism reached its lowest point in the reign of Mayor Barry Hatch, an ex-Mormon missionary, who attracted national notoriety for the table-thumping charge that a "billion Chinese are looking for a soft place to land. There's nowhere else but here. The whole valley is what they want."131

Reactionary movements such as RAMP inadvertently worked to politicize new immigrants and long-time Asian American and Latina/o residents. The nativistic and racist undertones of these movements ironically served to smooth certain intra-ethnic/racial tensions, creating opportunities for Asian American cooperation with Latina/o groups opposed to the divisive policies and politics of organizations such as RAMP. ${ }^{132}$

128. Davis, supra note 94 , at 207-08.

129. Id.

130. Id.

131. Id. Hatch was voted out of office by a coalition of Japanese, Chinese and Chicano voters in April 1990. Fong, supra note 97 , at 88.

132. AcUÑA, supra note 101, at 132 (describing how most of the communications that gave rise to coalition between Asian American and Latina/os were through their respective elites, which "had a critical mass of second- and third-generation leaders."). William Wei discusses some of the constraints on Asian American political power in Monterey Park:

[In the 1980s, t]he Asian American electorate was too small to win an election on its own. Asian Americans realized that the only possible way to acquire influence was to develop voting blocs and build political coalitions in major electoral districts. This was true in the April 1988 clection of Judy Chu, a former activist, to the Monterey Park City Council.... [Exit polling data] indicated that Chu received 88 percent of the Chinese vote and 75 percent of the Japanese American vote. But since Asian Ainericans make up only 35 percent of the city's electorate, success required significant support from others as well. And Chu got that support, receiving one in three European American and Latino votes. 
In 1990, redistricting was an important issue for both Asian American and Latina/o groups in Monterey Park, particularly given how recent municipal history showed what a lack of responsive representation can bring, at least on the city level. ${ }^{133}$ After the 1990 census, state political districts were redrawn to reflect population changes. This process was crucial for groups like Latina/os and Asian Americans, because it created the political units from which state and federal officials are elected. ${ }^{134}$ Traditionally, White politicians in Southern California have drawn districts so as to divide concentrated ethnic and racial

William Wei, The Asian American Movement 264 (1993) (citation omitted).

133. The need for redistricting was clear from the statistics:

[N]o Asian Americans were elected to the state legislature during the 1980s. The basis for any claim starts with raw numbers of population, and the 127 percent increase of the Califomia Asian American population in the 1980 s was due primarily to immigration. The increase of the Asian American population in the cities of the San Gabriel Valley was dramatic. Monterey Park's Asian American population grew by 90.6 percent, bringing the Asian American population to 57.5 percent of the city's population. Similarly, in nearby Alhambra, Rosemead, and San Gabriel, the Asian American population grew by 28 to 372 percent, forming 32 to 38 percent of the population in those cities.

NEW ASIAN IMMIGRATION, supra note 91, at 253-54.

However, note that the raw numbers must be considered in terms of numbers of eligible and registered voters, in which case, in the early 1990s, registered White voters outnumbered registered Asian American voters.

While the voter registration rate for the general population in California was about 73 percent in 1986 ... in Los Angeles County Japanese had a registration rate of 43 percent, while Chinese registered at 35.5 percent. Other groups had even lower rates: 27 percent for Fihipinos, 16.7 percent for Indians, 13 percent rate for Koreans and 4.1 percent rate for Vietnamese.... Should it not have been suspicious that the groups reported to have the lowest voter registration rates just happen to have the highest proportion of foreign-born members?... One study that [did] adjust for noncitizens... revealed registration rates ... for Asian Americans [that] were much higher: 77 percent of California Asian American citizens were registered compared to 87 percent of the whites... Only 69 percent of the Asians who registered voted compared to 80 percent of whites and 81 percent of African Americans. When groups were viewed separately, however, Chinese were more similar to whites in their voting pattern, while Vietnamese and Koreans had the lowest voting tumouts among Asians.

Bill Ong Hing, Making and Remaking Asian America Through Immigration Pol.icy, 18501990, at 153-54.

134.

Asians [have] had some electoral success in statewide elections, and since 1970 the number of Asians on city councils in California has doubled to 48... [However, i]n 1994, only 29 cities had populations that were more than one-fifth Asian, contrasted with 67 cities having Latino majorities, and an additional 244 with more than one-fifth of the population Latino.

AcuÑa, supra note 101, at 132; see also Philip OKaMoto, UCLA AsIAN AMERICAN StUdies Center, A Practical Guide to the Technical. Aspects of Redistricting (1991); Paul Ong \& TANia Azores, UCla Asian AMerican Studies Center, Reapportionment and Redistricting IN A NuTShell, (1991); Angelo N. Ancheta \& Kathryn K. Imahara, Multi-Ethnic Voting Rights: Redefining Vote Dilution in Communities of Color, 27 U.S.F. L. REv. 815 (1993). 
groups geographically, thereby diluting their chances of electing a minority representative as well as their general political influence. ${ }^{135}$

Following the 1990 census, the Coalition of Asian Pacific Americans for Fair Apportionment submitted oral and written testimony to the California State Assembly arguing that "there was such an entity as an 'Asian American' community."136 In 1991, former Monterey Park Mayor and City Council member Judy Chu expressed worries in testimony before the California State Senate Committee on Elections and Reapportionments that, "[w]ithout concentrated districts, the ability for Asian Americans to express their concern about issues will be diluted." 137 As an example of the need for Asian Americans to politically band together, Chu cited "attempts to restrict languages other than English from being spoken in public, from being written on any city materials that went to the public, and from being on commercial signs. . . [and] attempts to prevent foreign-language materials from being in [the Monterey Park] library." political representation and "advocates for programs that will help Asian immigrant children and adults" to the Asian American community. ${ }^{139}$

135. See Tania Azores \& Philip OKamoto, UCla Asian American Studies Center, asian Pacific american Awareness and Involvement in Redistricting (1991) (stressing the importance of community education and outreach in the Asian Ameriean community with regard to redistricting); HiNG, supra note 133, at 153-54 (noting that stereotypes of Asian Americans fuel the popular perception of their electoral ineffectiveness); MiNoRITY VoTe Dilution (Chandler Davidson ed., 1984) (cataloging various schemes which have been used historically to disempower minority eommunities); PaUl ONG et al., UCla Asian american Studies Center, Redistricting and Political Empowerment of Asian Pacific americans in Los Angeles: A Position PAPER (1991) (describing how to forge links between numerical strength and political power via the redistricting process); William Tamayo et al., UCLA ASIAN AMERICAN STUdies Center, The Voting Rights of Asian Pacific Americans (1991) (describing the importance to Asian American communities of political representation at different stages of the electoral process).

136. While we support the uses of a term like "Asian American," (or Latina/o), we also recognize the important limitations and pitfalls arising from the use, strategic or otherwise, of such a category. See Robert S. Chang, Toward an Asian American Legal Scholarship: Critical Race Theory, Post-Structuralism, and Narrative Space, 81 CaLIF. L. Rev. 1241, 1257 n.66, 1 As1an L.J. 1, 17 n.66 (1993) ("1 recognize that there is no essential Asian American identity and no singular Asian American group); Lowe, supra note 28, at 30 ("[E]ssentializing Asian American identity and suppressing our differences-of national origin, generation, gender, party, class risks particular dangers; [it may] inadvertently [support] the racist discourse that constructs Asian as a homogenous group, that implies we are 'all alike' and conform to 'types'.").

137. Saito, supra note 109, at 57-58 (quoting Judy Chu, testimony delivered in Los Angeles to the California Senate Committee of Elections and Reapportionment (March 9, 1991)).

138. Id.

139. Id. 
Asian American groups also recognized the necessity of working with Latina/o groups on redistricting issues after the 1990 census, although building and maintaining interracial and interethnic coalitions is often a difficult task. ${ }^{140}$ Many, but not all, new Asian immigrants in Monterey Park occupied high end employment, while many Latina/os held more marginal middle- and low-end service or manufacturing jobs. ${ }^{141}$ These class differences were further exacerbated by the presence of language barriers and other cultural differences. So it was unsurprising that tensions existed between Asian American and Latina/o groups in Monterey Park. Still, in the early 1990s, Latina/os and Asian Americans in the San Gabriel Valley "recognized the strengths of the other. Asian Americans had much to learn from Latino organizations that had gained political and legal knowledge through their successful court cases, such as Garza v. County of Los Angeles."142 While the

140. See, e.g., Lawrence Bobo \& Vincent L. Hutchings, Perceptions of Racial Group Competition: Extending Blumer's Theory of Group Position to a Multiracial Social Context, 61 AM. Soc. REv. 951 (1996) (describing obstacles to inter-group cooperation and coalition arising from social distance, spatial segregation, and inter-group stereotyping and rivalry); Lawrence Bobo, The Color Line, the Dilemma, and the Dream: Racial Attitudes and Relations at the Close of the 20th Century (1995) (unpublished manuscript, on file with author) (discussing the need to break through the strict color line with respect to residential segregation in order to reduce social and economic distanee and create working coalitions); Carole Uhlaner, Perceived Discrimination and Prejudice and the Coalition Prospects of Blacks, Latinos, and Asian Americans 339, in RACIAL AND ETHNIC Politics IN California (Byran O. Jackson \& Michael B. Preston eds., 1991) (comparing differential perceptions of race-based discrimination in schools, workplaces and residential neighborhoods as they bear on possible cooperation between groups of color).

To further underline the difficulty (and importance) of interracial/ethnic alliance and coalition work, consider how the domestic U.S. racial discourse tends to pit groups against each other in complex and frustrating ways. For example, Blacks and Whites might find commonality opposing higher immigration levels (which demagogues say would reduce Black jobs). However, on questions of affirmative action for jobs or education, Latina/os may find themselves aligned with Blacks against Whites and Asian Americans. But on opposition to English-Only and harsh immigration and welfare laws, Latina/os and Asian Americans may find themselves working together, and so on.

141. AcUN̄A, supra note 101 , at 132 "'A significant sector of Asian immigrants who have arrived in the United States since 1968 have been better educated or belonged to a higher social class than Blacks and Latinos.").

142. Saito, supra note 109, at 60 . For an example of this important line of cases, see Thornburg v. Gingles, 478 U.S. 30, 50-51 (1986) (holding that to demonstrate that redistricting has a racially discriminatory effect on a minority group under Section 2 of the Voting Rights Act, the group must show three threshold conditions: (1) that the minority group "is sufficiently large and geographically compact to constitute a majority in a single-member district"; (2) that the minority group is "politically cohesive"; and (3) that the majority "votes sufficiently as a bloc to enable it... to defeat the minority's preferred candidate." Based on "the totality of the circumstances," the plaintiff must show that the minority group has been denied an equal opportunity to "participate in the political process and to elect representatives of their choice."); Garza v. County of Los Angeles, 918 F.2d 763, 771 (9th Cir. 1990) ("Intentional discrimination may be shown if a legislative body chooses fragmentation 
Asian American population was increasing rapidly in Monterey Park, Latina/os were still the largest demographic minority group in the San Gabriel Valley, and "[p]olitical realities dictated that Asian Americans must work with Latinos."143 Leland Saito observed that in the post1990 redistricting discussions that politically remapped the San Gabriel Valley,

Asian Americans and Latinos understood that the political clout of both groups supporting one set of redistricting plans for the region would increase the possibility of the legislature adopting the plan. Most importantly, they also knew that if Asian Americans and Latinos were pitted against one another, both groups could end up losing. ${ }^{144}$

The two groups faced several problems. First, creating a district that maximized Asian American voting influence did not necessarily jibe with the goal of keeping the Asian American population together, particularly if doing so lumped Asian Americans with politically conservative Whites/Anglos. ${ }^{145}$ Second, there was a Latino incumbent Democrat, Xavier Becerra, in Monterey Park, who was protected by the Voting Rights Act. Assemblyman Becerra's chances for reelection might be damaged if his district were redrawn to include certain areas of high Asian concentration and growth that also housed an extremely active and very conservative White/Anglo Republican population. ${ }^{146}$ This created a potential divergence of interest for Latina/o, Asian American and White/Anglo communities in the area. ${ }^{147}$

of a minority population as an avenue to preserve incumbencies, and ... [t]here is some injury to the protected group.").

143. Saito, supra note 109 , at 61 .

144. Id. at 61. But see FoNG, supra note 97, at 71-72 ("Asian American politicians in California are more likely to be elected by votes of other ethnic groups .... Given the demographic composition of [Asian American-represented] districts, it would be political suicide for [an] Asian American[1 [politician] to pursue solely Asian American votes.").

145.

[C]reating a district that would maximize Asian American political influence does not necessarily result from just grouping the largest number of Asian Americans possible in one district. The northem cities were areas of heavy Asian American growth but also contained large numbers of politically conservative Anglos who may not support issues important to Asian Americans, such as more open immigration policies and bilingual voting materials. Saito, supra note 109 , at $62-63$.

146. See id. at 63; AcuÑA, supra note 101, at 132-33.

147. See Yamamoto, supra note 111, at $43-44$ (noting the shifting and, at times, problematic nature of the racial category of "Asian American"). For example, in the Monterey Park redistricting situation, when are (or rather, when should) questions of divergent nationality, ethnicity, class and immigration status be deferred for the sake of pan-ethnic unity and when should such differences within a group be foregrounded? 
In the end, the Asian American and Latina/o groups were able to propose a district including areas of greatest Asian and Asian American population and growth, while still maintaining a majority Democratic voting base that was favorable to Latina/o issues. Despite Governor Pete Wilson's veto of the Asian American/Latina/o coalition's redistricting plan for the San Gabriel Valley, the California Supreme Court adopted the proposed plan in early 1992. The redistricting plan "created a new assembly district, 49, which followed the recommendations of the valley coalition by grouping [together] the four cities of Asian American concentration."148 Some observers noted that "[t]he San Gabriel Valley was the only region where such close working ties existed between Asian Americans and Latinos." 149

The coalition of Asian Americans and Latinos remains fragile and tentative, with no guarantee of the redistricting conditions after the 2000 census. ${ }^{150}$ However, Eric Yamamoto points out that, "by the year 2000,

148. Saito, supra note 109 , at 65.

149. Id. But cf. ACUN̄A, supra note 101, at 132-33 (noting commonalities of struggle that could be sources of Asian American and Latina/o solidarity).

150. See ACUÑA, supra note 101, at 132; WEI, supra note 132, at 267-69. Note the fragility of such interracial/interethnic coalitions (as well as intra-group tensions) as illustrated by post-1989 attempts to create two City Council districts with Asian American pluralities in New York City-one including Manhattan's Chiuatown and the other in Flushing, Queens, another site of heavy migration and investment by Asian diaspora capital and significant immigration:

[D]emographic data showed that Asian Americans fell short of a majority in any one area; so, at most, they could carve out only one so-called Asian American district.... The Asian American community proposed two conflicting redistricting plans. The central issue was, With whom should Asian Americans ally themselves-European Americans or Latinos?

... [P]lan A ... joined Chinatown to liberal European American areas [and] because liberal European Americans had shown a willingness to vote for Asian American candidates... [this plan] gave the community a better chance of electing one of its own.... [Advocates of this plan] argned that combining minority groups into a siugle district ... "not only runs the risk of blocking Asian representation but risks having all the minority groups defeated in favor of a white candidate."

... [Another Asian American group] proposed a multiracial district plan that joined Chinatown to neighboring Latino enclaves... [based on the] underlying belief... that "immigrant Chinese and Hispanic communities have common interests not shared by wealthier white voters, and together they can comprise a district that is 83 percent minority-enough to elect a minority candidate." [Advocates of the Asian-Latino district argued that Plan A (the Asian-white district)] "sacrificed coalition-building among working class people of color... [who have] successfully united in the past to win affordable housing, health care, immigrant services and bilingual education."...

... [Plan A was eventually adopted, creatiug] an "Asian plurality" district... [consisting] of about 41 percent European Americans and 38 percent Asian Americans, with the remainder mainly Chicanos-Latinos....

... [However, the victory for advocates of the Asian-white district] proved to be a hollow one. In the special 1991 Democratic party primary election, [their] candidate, Margaret Chin, lost her bid for the District 1 seat to Kathryn E. Freed (additionally there was a Republican candidate, Fred Teng, who Freed defeated in November) ... [which is] tantamount to winning the November general election.... 
the familiar characterization of black versus white will no longer describe or explain American race relations. America in the twenty-first century will be a nation of minorities." Furthermore, Yamamoto begins developing "a theory of inter-group alliances based on the concept of 'interracial justice." Such a theory, Yamamoto suggests, must "acknowledge[] historical white dominance and contemporary white rhetorical, institutional and economic influence," but must also "decenter[] whiteness as the singular referent for determining racial identities and interracial tensions." 151 By carefully examining "the 'constrained' yet meaningful agency of nonwhite groups in terms of interracial conflict and healing," Yamamoto thinks we may be able to engage in "a hard acknowledgement of the extent to which nonwhite racial groups situationally have oppressed and continue to oppress one another," but also make a "commitment to affirmative efforts to redress past and continuing harm." 152 In Monterey Park, we may be witnessing an important but tentative step towards inter-group relations that focuses at least partly on "racial group efforts towards transforming 'power over' one another into 'power to' cooperate and coexist, toward living together peaceably and working together politically."

\section{Monterey Park: The Changing Role(s) of Race(s)}

Because of the tremendous influx of Asian immigrants and dramatically changing demographics in the past thirty years, Monterey Park is an interesting site to explore the political economy of race in the United States. New Chinese immigrants to Monterey Park are changing the way long-time Asian residents are perceived, and the migration of middle-class Asians and Latina/os to the area emphasizes the role of race in power relations among different races, as various groups move fluidly from oppressed to oppressor and back again. ${ }^{154}$

WEI, supra note 132, 267-69 (citations omitted).

151. Yamamoto, supra note 111 , at 70.

152. Id.

153. Id.; see also Hing, supra note 110 (discussing the unpalatable choice between a homogenizing assimilationist approach to immigration and racial diversity and a fractionalized and essentialized tribalism, as well as possible altematives).

154. See Yamamoto, supra note 111, at $64-65$ (discussing the importance of historicizing disparities in intergroup power relations to avoid the pitfalls of essentialized, and contradictory, stereotypification). Cf. James A. Regalado, Community Coalition-Building, in THe Los AngelzS RIOTS: LESSONS FOR THE URBAN FUTURE 230 (Mark Baldassare ed., 1994):

[C]oalition failures in this period have been due to a combination of conceptual, structural and organizational problems: (1) improperly understanding the complexity of race and class relations and issue in Los Angeles, inclusive of a reliance on and not going beyond building middle-class membership and constituencies; (2) becoming too comfortable with critically 
As we discussed in Part 1 , not only are certain immigrants themselves racialized when they enter the predominantly White United States, they also help to racialize differentially many people who have lived in the United States all of their lives. ${ }^{155}$ Many people remain "immigrants" and foreigners simply on the basis of their phenotypical physical features, no matter where they were born, their official citizenship status, or how many generations their family has been in the United States. ${ }^{156}$ The influx of recent Chinese immigrants in Monterey Park have affected the lives of many Japanese Americans living there, beyond their outward influence on the economics and appearance of the city. They are altering the personal identity of Japanese Americans, who are now often seen as Asian by Whites/Anglos and as one of them, rather than as longtime residents whose community is being altered by newcomers, just as it is for Whites/Anglos or, for that matter, long-term Latina/o residents. ${ }^{157}$ One Nisei explained,

I think it's kind of a bad thing for us, that the Caucasian categorizes us as Chinese. I would like the Caucasian people to think that there is a difference between the Japanese and the Chinese, but they don't do it here in Monterey Park because they see me, they think, hey, here's another Chinese.... [Japanese Americans] should wear buttons saying, "I'm Japanese, not

unchallenged concepts of pluralism and multiculturalism; (3) being oblivious to the degree to which traditional theories and beliefs of representative democracy and public policy formation are not working for communities of color; (4) failure to broadly recognize and confront the degree to which anti-democratic corporatist approaches have failed those most in need of economic development and job creation; (5) failure to set clear and strategic goals, realizable objectives and targeted activities and outcomes; and (6) being unwilling to Id. overcome provincial outlooks and agendas.

155.

The concept of "differential racialization" responds in part to the problem of essentialism and in part to questions of group power. It acknowledges that historical and contemporary influences racialize different racial groups and subgroups differently.... "Differential isolation" may exist even within subgroups, as between the first and second waves of Vietnamese American immigrants. ... More "established" immigrant groups, with greater access to political power ... may organize around mobility issues ("glass ceilings"), while recent immigrant groups may focus on "survival issues" (funding for language classes and job-training programs).

Yamamoto, supra note 111 , at 61 .

156. New AsIan IMMigRaTion, supra note 91, at 3.

157. The Japanese-American reaction to the Chinese immigrants is expressed by one Nisei: "To emphasize the negative impact of the Chinese on Monterey Park, he quoted his son's remarks on returning home after a few years of military service overseas: "God damn, dad, where the hell did all these Chinese come from? Shit, this isn't even our town anymore."' Id. at 238. 
Chinese," just like some Chinese who wore buttons during World War II, "I'm Chinese, not Japanese."158

Despite the ethnic, historical and cultural differences and resentment towards new Chinese immigrants, ${ }^{159}$ many members of the Japanese American community have also begun seeing themselves as "Asian" or "Asian American," at the very least in their voting interests. ${ }^{160}$ The same Nisei that expressed a desire to be distinguished from the Chinese voted for Lily Chen, a Chinese immigrant, for Monterey Park's city council in 1982, because he recognized the need for "Asian American" representation.

As racial categorization and discrimination impose and construct an Asian American racial identity from without, many Asian Americans find that they also internalize and "customize" this racial identity in an affirmative, community-building sense that creates a space for resistance, political and otherwise, to external subordination. Individual ethnic groups, such as Japanese, Chinese, Korean, Cambodian, Vietnamese, Thai, Filipino or South Asians may not be large enough to have a significant effect in our political system. The strength of numbers, the shared experience of discrimination, and White perceptions of Asian Americans as "foreign" all serve to draw Asian Americans from different ethnic groups together. One Asian American describes his first encounter with racial discrimination and how it changed his perception of himself:

It was on a late May afternoon in 1969 , three months after he had left the Philippines for New York City, that Peter Bersamin says he began to realize he was Asian. Driving up to Cape Cod, he stopped at a cottage with a sign promising vacancies. But when Mr. Bersamin asked about a room, the keeper looked at him, told him no and closed the door. "Before I got back to the car I knew it," he said. "That was my first experience with racial discrimination and the beginning of my awareness as being somebody other than white." Until then, Mr. Bersamin had identified himself only as Filipino. But after

158. Id.

159. Some of the attitudes are expressed in this Nisei quote:

First of all, I think that the Nisei and Sansei [third-generation Japanese Americans] can speak English a lot better than the Chinese can. And I think we probably behave better in public than they do: we're not as boisterous in public, we're not as pushy in public as the Chinese are. 1 mean you don't see a Japanese person crowding in line or talking at the top Id. of his voice.

160. Yamamoto, supra note 111, at 60 (noting that the racial identity "Asian American" ellides differences among distinct Asian groups and increases their social and political power). 
meeting other Asian immigrants in Queens over the years, the 50-year old psychologist has come to feel less part of a national or ethnic group and more part of a racial one. He now felt kinship for the Chinese, whom he had regarded suspiciously in the Philippines, and for the Japanese, whom his father, a colonel during World War II, hated so much he refused to stop in Tokyo on a trans-Pacific flight. ${ }^{161}$

This story illustrates the process of internal racialization that members of many ethnic groups experience within the U.S. The political appeal of the strength of numbers provides a powerful incentive for members of these groups to band together. However, there may also be disadvantages to such internal racialization. The interests and identity of numerically smaller and temporally junior ethnic groups, such as the Vietnamese, Thai or Cambodians, may be swallowed up by the concerns of larger, more economically powerful and better politically organized groups. In addition, internal racialization may encourage the stereotyping of other racial groups, leading to further discrimination, both internally and externally. ${ }^{162}$

Although in Monterey Park, Asians of many different ethnic groups and also Latina/os were able to work together politically for their greater interests against a traditional White/Anglo-dominated political system on the issue of redistricting, many interracial tensions and prejudices among "minority" groups remain, particularly when African Americans are added to the calculation. ${ }^{163}$ For example, why are racially

161. Onishi, supra note 83, at A1.

162. See Lynne Duke, Blacks, Asians, Latinos Cite Prejudice by Whites for Limited Opportunity, WASH. Post, Mar. 3, 1994, at A9; Steven A. Holmes, Survey Finds Minorities Resent One Another Almost as Much as They Do Whites, N.Y. Times, Mar. 3, 1994, at B8 ("Presenting a portrait of a highly Balkanized country, a national survey indicates that Black, Hispanic and Asian Americans say they have fewer opportunities than whites. But the survey also indicates that the antipathy these three minorities feel toward one another nearly equals the resentment they collectively feel toward whites.") (emphasis added).

163. See Larry Gordon, Prejudice Called Main Cause of Housing Segregation, L.A. Trmes, December 23, 1996, at A1. This study was undertaken by UCLA Professor Lawrence Bobo and rejected the hypothesis that residential segregation resulted from objective differences in socioeconomic status that left Blacks and Latinos unable to afford desirable housing. The study found that:

Latinos and then Asians expressed the strongest preferences for living in neighborhoods where their own groups were in the overwhelming majorities... [which] may reflect the language barrier faced by new immigrants and the initial reliance on churches, grocery stores and community groups that cater to their needs... . Native-born Latinos and Asians seem to have less desire for such ethnic neighborhoods than the foreign-born.

Id.

See also Rachel F. Moran, Demography and Distrust: The Latino Challenge to Civil Rights and Immigration Policy in the 1990's and Beyond, 8 LA RAZA L.J. 1, 10 (1995) (noting that the color line 
segregated outcomes in the residential housing market (underwritten by municipal sovereignty regarding zoning) more or less shielded from judicial scrutiny, whereas, in the post-Shaw era, attempts by state legislators to take racialized space into account when redrawing electoral districts are dismissed as "mere racial politics" and presumptively illegitimate ${ }^{164}$ Eric Yamamoto talks of the importance of making the "hard acknowledgment of the extent to which nonwhite racial groups situationally have oppressed and continue to oppress one another."165

that works to spatially segregate African Americans is somewhat more porous for Latina/os, Professor Moran writes that "[a]ffluent Latinos typically have been more able than African Americans to escape segregated neighborhoods by moving to the suburbs; as a result, many Latinos believe that the most significant impediment to upward mobility is neither race nor ethnicity, but poverty.").

On the uneasiness between African American and Latinalo communities, see Colloquy: Our Next Race Question: The Uneasiness Between Blacks and Latinos, HARPER's MaGazinE, April 1996, at 55 (containing discussion between Jorge Klor de Alva, Earl Shorris and Cornel West in which Jorge Klor de Alva says that "Blacks are more Anglo than most Anglos because, unlike most Anglos, they can't directly identify themselves with a nation-state outside the United States... However unjust and painful, their experiences are wholly made in America." Cornel West replies: "I want to try and convince these Latino brothers and sisters not to think of black folk as Anglos. That's just wrong. Now, they can say that we're English-speaking moderns in the United States who have yet to be fully treated as Americans. That's fine.").

164. One distinction might turn on an analysis that looks at the "public-ness" or "private-ness" of such determinations, i.e., "private" individuals are merely acting on their preferences when they "choose" to live in an all-White neighborhood, whereas a legislature engaging in redistricting is engaging in an untoward "public" intervention in the political process. We would, however, point to the indeterminacy of such characterizations. For example, one might characterize the "private" real estate as fundamentally structured by judicial and legislative interventions (actions and nonactions) that produce racialized (and illegitimate) spaces, and the actions of a legislature engaging in redistricting as "merely" recognizing the aggregate choices of "private" individuals in the market. The point is that such indeterminate analyses fail to confront the underlying racial and other politics of such spaces. See generally Richard Thompson Ford, Geography and Sovereignty, 50 STAN. L. REV. (forthcoming 1997) (copy on file with author).

165. Yamamoto, supra note 111, at 70; see also Edward T. Chang, Jewish and Korean Merchants in African American Neighborhoods: A Comparative Perspective, in Los ANGELEs, supra note 109, at 5; Jeff Chang, Race, Class, Conflict and Empowerment: On Ice Cube's "Black Korea", in Los ANGELES, supra note 109, at 87 (assessing possibilities for cooperation and coalition in post-I992 Uprising Los Angeles as filtered through popular cultural imagery); Sumi K. Cho, Korean Americans vs. African Americans: Conflict and Construction, in READING RoDNEY KING: READING URBAN UPRISING 178 (Robert Gooding Williams ed., 1993) (describing the problematic construction of both Koreans and African Americans in mainstream U.S. racial ideology); Thomas L. Dumm, The New Enclosures: Racism in the Normalized Community, in READING RODNEY KING, supra, at 157 (describing the panoptic and neo-totalitarian spaces of the contemporary core city, as exemplified by 1990s South Central Los Angeles); Armando Navarro, The South Central Los Angeles Eruption: A Latino Perspective, in Los ANGEles, supra note 109, at 69 (describing the puzzling lack of visibility of Latina/os in the media coverage of the L.A. Uprising); Ella Stewart, Communication berween African Americans and Korean Americans: Before and After the Los Angeles Riots, in Los ANGELES, supra note 109, at 23 (discussing tensions between African Americans and Koreans in I992 Los Angeles, arising in part from cultural, lingnistic, nationality-based, race and class gulfs in 
In Monterey Park, we have seen the changing demographics and noted the contingent alliance between Asian Americans and Latina/os. This alliance provides insight into the fluidity of the role of race in U.S. society and politics. ${ }^{166}$ For example, on a less sanguine note, Asian Americans and Latina/os may implicitly or explicitly also unite locally to protect their property values by continuing to promulgate institutional practices that exclude African Americans from communities such as Monterey Park. ${ }^{167}$ Recall that Monterey Park's African American

communications and knowledge); Arvli Ward, Which Side are You On? The Rebellion Causes Pride and Pain for One Observer Who is Half Asian, Half Black, in Los ANGELES, supra note 109, at 109 (describing the contradictory and painful pulls of belonging to two racial groups which appeared to at loggerheads).

166. Part of the work necessary to building and sustaining interethnic and interracial alliances and coalitions involves dealing with recognition of past wrongs inflicted by one group upon another, as well as the important task of devising redress for such wrongs. Eric Yamamoto writes:

[H] ealing, whether by individual or group, entails some combination of acknowledgment of the humanity of the Other and of the sources of the conflict (including the historical roots of present conflict), acceptance of appropriate responsibility (often in the form of an apology) and material change (structural alteration of the relationship). [There is also] ... the notion that healing of wounds from perceived wrongful acts, while often messy and incomplete, is a foundation for future communal, or at least cooperative, action. [Lastly,] ... approaches to intergroup healing incorporate legal concepts only indirectly and move beyond formal notions of legal justice.

Yamamoto, supra note 111, at 69 . In the Los Angeles County survey, "about $28 \%$ of black respondents said they had experienced housing discrimination, compared to $9 \%$ of Latinos and $5.8 \%$ of Asians. Those include complaints about so-called steering by real estate agents to minority areas, overly stringent credit policies and being told-falsely-that desirable houses or apartments had suddenly become unavailable." Gordon, supra note 163 , at B1.

167. Briefly put, the group-agency argument would begin examining the variable degree of Asian American and Latina/o complicity in maintaining and materially benefltting from the historical and ongoing exclusion of African American from heretofore White, but now, in communities like Monterey Park, Asian, Latina/o and White residential areas. Put differently, there has been a definite and unfortunate link between exclusion of African Americans and appreciating real estate values in suburban U.S. real estate, which has been exploited and indeed encouraged at different times by the federal government, judicial interpretation of real covenants, state legislation, municipal zoning practices, unscrupulous realtors and banks engaging in practices such as "blockbusting" or "redlining" in distressed urban areas, as well as extralegal violence. While the Civil Rights Statutes of the 1960s such as Title VIII, the Fair Housing Act of 1968, may have made many segregationist laws and practices illegal, they may have cleared the way for upwardly mobile Latina/os and Asian Americans (and a relatively few African Americans) to move up and out from the barrio or Chinatown. However, the core cities were left to further decay in the wake of such flight. Additionally, the Civil Rights Statutes of the 1960s did not bar economic discrimination, premised on minimum lot size requirements, single family zoning, and minimum cost requirements for suburban property, as long as they were enacted with no overt racial animus. Thus, economic class served as an effective proxy for race in many residential real estate contexts. To the extent that there may exist a level of group complicity in such race-based exclusion, there may also be group responsibility to attempt to alleviate some of the harms arising from perpetuation of American Apartheid. At the very least, such responsibility might begin with educating one's self and other group members of the still pervasive legacy of residential racial segregation. See generally DAvis, supra note 94, at 165-66 (discussing how the idea of defense of property values and municipal sovereignty combined in the 
population remained at or below $1 \%$ from 1960 to 1990, even while Asian Americans and Latina/os made significant inroads into the previously all-White residential housing market. From the point of view of an African American, those Asian Americans and Latina/os might as well be White, because their class-not their race, or rather, their non-Black status-has led them perhaps inadvertantly to adopt the role of players in a system that masks residential racial discrimination in the seemingly more neutral guise of mere protection of neighborhood property values. However, these same groups, whose interests may diverge on the issue of appreciating property values, must somehow find ways to join forces statewide to be able to fight the nativistic racism and backlash of a Proposition 187. In that case, some Asian Americans may find themselves oppressed, and their interests are aligned with those of African Americans and Latina/os and opposed to those of the Whites. Or Asian Americans may find themselves deployed by Whites as a "model minority" to police African Americans and Latina/os as was partially the case with the so-called "California Civil Rights Initiative," Proposition 209.

Another interesting aspect of minority group alliances is the inevitable tension that accompanies attempts at coalition. Do Asian Americans, who outnumber the Latina/os in Monterey Park but not in the San Gabriel Valley or Southern California, resent having to rely on them in elective office ${ }^{168}$ Do the Latina/os fear betrayal should Asian

1960 s, 70 s and 80 s to produce a racially segregated patchwork of municipalities in Southern California that had ostensibly happeued via seemingly benign "market forces"); MASSEY \& DENTON, Amrrican Apartreid, supra note 92; Cheryl 1. Harris, Whiteness as Property, 106 HaRv. L. Rev. 1709 (1993) (discussing how "Whiteness," i.e., the absence of Blacks, has been an important element in defining and maintaining property values in the U.S.); see also Milliken v. Bradley, 418 U.S. 717 (1974) (holding that interdistrict school busing as a remedy for school segregation was impermissible across municipal and school district borders); Keith Aoki, Race, Space and Place: The Relation between Architectural Modernism, Post-Modernism, Urban Planning and Gentrification, 20 FORDHAM URB. L.J. 699 (1993) (discussing the pervasiveness of notions of segregation in 20th century U.S. urban planning).

168. See Yamamoto, supra note 111, at 71. Warning of conservative attempts to hijack a discussion of intergroup responsibility for color-on-color oppression, because it may let Whites off the hook, Yamamoto writes that such a discussion:

can be easily yanked out of context ... [and] misused in at least two ways. First ... it can be misused to overstate the extent of racial group agency in the construction of group identity, the elevation of group socio-economic status and the forging of intergroup relations. ... Second, in light of current anti-affirmative action initiatives, the discussion can be misused to absolve whites of responsibility for continuing structural subordination of racial groups and to recast whites as primary "victims" of racism.

Id.; see also Gabriel Chin et al., Beyond Self-Interest: Asian Pacific Americans Toward a Community of Justice: A Policy Analysis of Affirmative Action (1996) (organizing and stating the arguments why Asian Americans should support Affirmative Action programs). 
Americans gain those offices in the perhaps misguided belief that Asian Americans would be less motivated than Latinalos to fight Proposition 187 or Proposition 209-type policies? On an intragroup level, consider, for example, the resentment of the long-established Japanese-American community toward the supposedly more ostentatious Chinese newcomers who have, in part, caused them all to be grouped together in a pejorative manner by Whites/Anglos. ${ }^{169}$ Why are the Japanese Americans resentful of the Chinese newcomers rather than of the Whites, who initially promulgated the pervasive, false and derogatory stereotypes of Asian immigrants for over a century?

It is important to recognize the dynamic role of certain contingent, but nonetheless salient, constructions of ethnic and racial group identity that confront non-White immigrants to the U.S. It is also important not to overestimate the determinacy of such constructions nor the role of immigrant groups in the subordination of other groups-so that blame and retribution are not tragically misplaced, as they were in the 1992 Los Angeles uprising. ${ }^{170}$ This is the issue of individual and group agency that a city like Monterey Park asks us to consider. ${ }^{171}$

169.

There is also some resentment among the Japanese about suddenly being thrown into the same category as recent immigrants, because of their skin and facial characteristics. "Everybody gets lumped together," fumed one young woman. "We're all grouped as

"Asians'." There have been some reports of instances of Japanese teen-agers being mistaken for Chinese and being beaten up by young toughs from other ethnic groups.

Edmund Newton, Japanese in Monterey Park 'Golden Ghetto' Erodes as Young Move Away, LA. Times, Apr. 19, 1987, at A10.

170. See READING RoDNEY KING, supra note 165; Hing, supra note 110; Ikemoto, supra note 110; Robinson, supra note 110.

171. See Glenn Omatsu, The 'Four Prisons' and the Movements of Liberation: Asian American Activism from the 1960s to the 1990s, in The STATE of Asian AMERICA: ACtivism AND Resistance IN THE 1990s, at 66 (Karin Aguilar-San Juan ed., 1991) ("[As Asian Americans seek to empower our communities][w]ill we fight only for ourselves, or will we embrace the concerns of all oppressed peoples? Will we overcome our own oppression and help to create a new society, or will we become a new exploiter group in the present American hierarchy of inequality? Will we define our goal of empowerment solely in terms of individual advancement for a few, or as the collective liberation for all people?").

John Horton provides a more recent twist on the slow-growth issue in Monterey Park:

[The 1993 gambling card club controversy in Monterey Park] involved an unprecedented level of interethnic, interclass, and immigrants/established residents unity.... Particularly noteworthy was the strong presence of two previously separated and sometimes antagonistic groups-working-class Latinos (immigrants and U.S.-born) from East Los Angeles and the poorer sections of Monterey Park.... [and] Asians [who] were particularly sensitive to the danger of gambling tarnishing the image of America's first majority-Asian city. Latinos were particularly sensitive to the location of the facility in their sector of the city.... In spite of the differences in class, nativity, ethnic background, and political style, the protesters shared the determination to protect their neighborhoods against the unwanted projects of a big developer. Improving the deprcssed quality of local life had 
Finally, centering the immigrant in our analysis inevitably involves taking cognizance of the borders between and within racial groups as they are constructed within the United States, borders which undergo sometimes striking changes as the immigrant crosses the national border. The project of rethiuking borders by centering the iminigrant in the inter/national imagination involves examining the effects of subnational borders on political processes that surface on the state level in terms of redistricting, and on the municipal level in terms of zoning and the demarcation of school districts. This project should also examine the operation of residential access, which until recently has occurred along strict racial lines. The practical effect of this project is to cross these borders, build links, and forge coalitions in an attempt to shortcircuit the insidious political economy of nativistic racism.

\section{CONCLUSION}

One challenge for a critical Asian American legal scholarship and for LatCrit discourse is to disable the regressive construction of borders that enables nativistic racism. In doing so, we must approach this work with "a critical awareness of how borders have been (and continue to be) systematically policed and for whose ideological benefit and material profit." 172

Last year, the Immigration and Naturalization Service (INS) conducted a sweep through four southern states to round up and deport undocumented agricultural workers. They called it Operation SouthPAW, "PAW" standing for "Protecting American Workers." The round-up took place mostly before and after the harvest was in. ${ }^{173}$ There is no question that Operation SouthPAW worked to police our borders, but for whose ideological benefit and whose material profit? And the material profit here is not limited to farmers and agribusiness-

been a constant struggle in working-class neighborhoods, which were often the dumping grounds for projects unacceptable to more affluent and powerful residents. ... The protest against gambling was significant in uniting neighborhoods ordinarily separated by class and parochialism.... Ironically, given the history of development issues in Monterey Park, Chinese and Latinos were united against a Chinese developer and his supporters, who included a contingent of Anglo leadcrs of the slow-growth movement.

Horton, Chinese Suburban Immigration, supra note 99, at 108-09.

172. Vera M. Kutzinski, Commentary: American Literary History as Spatial Practice, 4 AM. LITERARY Hist. 555 (1992). This quote is one of the opening epigrams in Michael AWKWARD, Negotiating Difference: Race, Gender, and the Politics of Positionality (1995).

173. We examine Operation SouthPAW in greater detail, and we use it as a starting point in Ibrahim Gassama, Robert S. Chang \& Keith Aoki, Foreword: Citizenship and Its Discontents: Centering the Immigrant in the Inter/National Imagination (Part II), 76 OR. L. REV. (forthcoming 1997). 
all "Americans" benefit and are thus complicit insofar as food prices are kept low. Asian American legal scholarship and LatCrit discourse enables us to bring incidents, like SouthPAW, to light and provides a framework for understanding the deeper origins of those practices.

Another challenge for Asian American legal scholarship and LatCrit discourse is to claim its space in America's racial landscape. Vera Kutzinski tells us that

[t] he way to rescind borders is of course to cross them and, in doing so, blur them, confuse them, make them permeable, open for traffic from all directions, and, as a result, realize that they have in fact been open all along, crossed by illegal traffic of all kinds-in short, that differences of the kind that do not settle down into binaries have already proliferated in our own backyards. ${ }^{174}$

The long and the short of it is that Asian Americans and Latina/os are neither Black nor White. ${ }^{175}$ We will not settle down into the Black/White binary. Most important, we are here-and we are not going away.

The project of rescinding borders includes upsetting the boundaries that privilege any simple binary, whether it be the Black/White racial paradigm, male/female, straight/queer. At times, this will be met with resistance. ${ }^{176}$ The challenge, then, is for Asian American legal scholarship and LatCrit discourse to work with Critical Race Theory, Critical Legal Studies, Feminist Legal Theory, and Queer Legal Theory to articulate a set of political commitments around which subordinated peoples and persons of goodwill can organize. ${ }^{177}$

This hard work is taking place at multiple sites. Our communities and coalitions are (and always will be), as Francisco Valdes has noted, "under construction." 178 This Article attempts to contribute to the LatCrit building project by upsetting borders and by centering the immigrant in our analysis.

174. Kutzinski, supra note 172 .

175. This statement does not deny the existence of Afro-Carribeans.

176. Some of this has been evident at recent Critical Race Theory Workshops and at the first LatCrit Theory Conference held at California Western School of Law in Spring 1996.

177. On February 22, 1997, the California Western Law Review hosted a symposium, Towards a Radical and Plural Democracy, at which participants of different critical legal genres tried to have this conversation. Some of the results may be seen in Symposium: Towards a Radical and Plural Democracy, 33 CAL. W. L. REv. 139 (1997).

178. Francisco Valdes, Foreword: Under Construction: LatCrit Consciousness, Community and Theory, 85 CAL.1F. L. REv 1087 (1997), 10 LA RAZA L.J. 1 (1997). 
LA RAZA LAW JOURNAL

CALIFORNIA LAW REVIEW 